\title{
H-Ras and K-Ras oncoproteins induce different tumor spectra when driven by the same regulatory sequences by
}

\author{
Matthias Drosten ${ }^{1}$, Lucía Simón-Carrasco ${ }^{1}$, Isabel Hernández-Porras ${ }^{1}$, Carmen G. \\ Lechuga $^{1}$, María T. Blasco ${ }^{1}$, Harrys K. C. Jacob ${ }^{2}$, Salvatore Fabbiano ${ }^{2,4}$, Nicoletta \\ Potenza $^{3}$, Xosé R. Bustelo ${ }^{2}$, Carmen Guerra ${ }^{1}$ and Mariano Barbacid ${ }^{1}$
}

\author{
${ }^{1}$ Molecular Oncology Programme, Centro Nacional de Investigaciones Oncológicas \\ (CNIO), Melchor Fernández Almagro 3, 28029 Madrid, Spain \\ ${ }^{2}$ Centro de Investigación del Cáncer and Instituto de Biología Molecular y Celular del \\ Cáncer, CSIC-Universidad de Salamanca, Campus Miguel Unamuno s/n, 37007 \\ Salamanca, Spain and Centro de Investigación Biomédica en Red-Oncología, Carlos III \\ Health Institute, Spain \\ ${ }^{3}$ Department of Environmental, Biological and Pharmaceutical Sciences and \\ Technologies (DiSTABiF), Second University of Naples, 81100 Caserta, Italy \\ ${ }^{4}$ Present address: Department of Cell Physiology and Metabolism, Centre Médical \\ Universitaire (CMU) and Diabetes Centre, Faculty of Medicine, University of Geneva, \\ 1206 Geneva, Switzerland
}

Corresponding authors: Matthias Drosten, Molecular Oncology Programme, Centro Nacional de Investigaciones Oncológicas (CNIO), Melchor Fernández Almagro 3, 28029 Madrid, Spain, Phone: +34917328000, Fax: +34917328033, E-mail: mdrosten@cnio.es and Mariano Barbacid, Molecular Oncology Programme, Centro Nacional de Investigaciones Oncológicas (CNIO), Melchor Fernández Almagro 3, 28029 Madrid, Spain, Phone: +34917328000, Fax: +34917328033, E-mail: mbarbacid@,cnio.es

Keywords: H-Ras / K-Ras / Ras oncoproteins / tumor development / oncogene-induced senescence

\section{DISCLOSURE OF POTENTIAL CONFLICTS OF INTERESTS}

None of the authors have any potential conflicts of interest. 


\begin{abstract}
Genetic studies in mice have provided evidence that H-Ras and K-Ras proteins are bioequivalent. However, human tumors display marked differences in the association of RAS oncogenes with tumor type. Thus, to further assess the bioequivalency of oncogenic H-Ras and K-Ras, we replaced the coding region of the murine K-Ras locus with H-Ras ${ }^{\mathrm{G} 12 \mathrm{~V}}$ oncogene sequences. Germline expression of H-Ras ${ }^{\mathrm{G} 12 \mathrm{~V}}$ or K-Ras ${ }^{\mathrm{G} 12 \mathrm{~V}}$ from the K-Ras locus resulted in embryonic lethality. However, expression of these genes in adult mice led to different tumor phenotypes. Whereas H-Ras ${ }^{\mathrm{G} 12 \mathrm{~V}}$ elicited papillomas and hematopoietic tumors, K-Ras ${ }^{\mathrm{G} 12 \mathrm{~V}}$ induced lung tumors and gastric lesions. Pulmonary expression of $\mathrm{H}-\mathrm{Ras}^{\mathrm{G} 12 \mathrm{~V}}$ created a senescence-like state caused by excessive MAP kinase signaling. Likewise, H-Ras ${ }^{\mathrm{G} 12 \mathrm{~V}}$ but not $\mathrm{K}-\mathrm{Ras}^{\mathrm{G} 12 \mathrm{~V}}$ induced senescence in mouse embryo fibroblasts. Label-free quantitative analysis revealed that minor differences in H-Ras ${ }^{\mathrm{G} 12 \mathrm{~V}}$ expression levels led to drastically different biological outputs, suggesting that subtle differences in MAP kinase signaling confer nonequivalent functions that influence tumor spectra induced by RAS oncoproteins.
\end{abstract}




\section{Introduction}

Mammals contain three Ras loci, H-Ras, K-Ras and N-Ras, that encode highly related proteins (1-4). Ras proteins are small GTPases that function as mitogenic switches to control the transmission of extracellular signals to the nucleus (1). They share extensive homology at their N-terminal half, a region involved in nucleotide binding and interaction with downstream effectors (2). Their unique features reside in their carboxyterminal half that includes the hypervariable region and a terminal domain known as the CAAX box (2). These structural motifs have been implicated in differential transport, post-translational processing and subcellular localization of the different Ras proteins $(3,4)$.

Early knock-out data revealed significant functional differences for the three Ras loci. Whereas $\mathrm{H}$ - and $\mathrm{N}$-Ras were dispensable for embryonic development, K-Ras was essential (5-7). These observations did not establish whether these differences were due to the intrinsic properties of their cognate Ras proteins or to their patterns of expression. This issue was solved, at least in part, when Potenza et al. replaced mouse K-Ras alleles by chimeric $\mathrm{K} / \mathrm{H}$-Ras alleles encoding functional $\mathrm{H}$-Ras proteins (8). These mice developed to adulthood despite the absence of K-Ras, indicating that the requirement for K-Ras alleles during embryonic development is primarily due to their pattern of expression. Yet, these mice displayed cardiovascular defects, thus raising the possibility that H-Ras and K-Ras proteins might have differential signaling properties, at least in certain tissues (8).

$R A S$ genes have also attracted interest due to their involvement in tumor development $(1,2)$. The overall incidence of each RAS oncogene varies significantly among tumor 
types (9). Whereas KRAS is frequently mutated in pancreatic, colorectal and lung adenocarcinomas, HRAS oncogenes are found in a limited percentage of tumors from the salivary gland, urinary track, cervix, or skin. On the other hand, NRAS oncogenes are present in melanomas and hematopoietic tumors. As of to date, the molecular basis for this incidence bias is still unresolved (9).

Mutant RAS genes also induce different phenotypes when expressed in the germline of patients suffering from RASopathies, a series of developmental defects that result from constitutive activation of RAS signaling pathways $(10,11)$. Oncogenic mutations in HRAS lead to relatively mild developmental defects in Costello syndrome patients (12, 13). In contrast, those KRAS mutations present in human tumors have not been found in RASopathy patients, suggesting that such mutations may cause embryonic lethality (14).

Similar results have been observed in mouse strains carrying genetically engineered Ras mutations. Whereas expression of resident K-Ras oncoproteins in the germline leads to early embryonic death, expression of an endogenous H-Ras oncogene is well tolerated and leads to developmental defects very similar to those observed in Costello patients (15-18). Likewise, germline expression of the partially activated K-Ras ${ }^{\mathrm{V} 14 \mathrm{I}}$ mutant isoform results in phenotypic defects that closely resemble those of Noonan patients (19).

Here we provide genetic evidence that the wild-type H-Ras and K-Ras proteins are bioequivalent in spite of their different structural and biological properties. We have also compared the spectrum of tumors elicited upon expression of the H-Ras ${ }^{\mathrm{G} 12 \mathrm{~V}}$ and $\mathrm{K}$ - 
$\operatorname{Ras}^{\mathrm{G} 12 \mathrm{~V}}$ oncoproteins from the same mouse K-Ras locus. These studies have revealed that these oncoproteins induce a different spectrum of tumors primarily due to differences in the intensity of MAP Kinase signaling that results from subtle differences in their levels of expression. Research. 


\section{MATERIALS AND METHODS}

Mouse strains. Generation of $\mathrm{K}-\mathrm{Ras}^{+/ \mathrm{LSLH}-\mathrm{RasG} 12 \mathrm{~V}}$ mice $\left(K^{\mathrm{HRaSV} 12}\right)$ is described in Supplementary information. KrasKI (8), HrasKI (8), H-Ras ${ }^{-/-}$(5), K-Ras ${ }^{+/ L S L G 12 V g e o ~}$ $\left(K^{\mathrm{V} 12}\right)(16)$ and $p 53^{\text {lox/lox }}(20)$ genetically engineered strains have been described. hUBC-CreERT2 ${ }^{21}$, Elas-tTA and tetO-Cre transgenic strains have also been reported $(21,22)$. Activation of the inducible CreERT2 recombinase was achieved by feeding the mice with a Tmx-containing diet (Harlan Laboratories). For activation of $\mathrm{H}-\mathrm{Ras}^{\mathrm{G}}{ }^{\mathrm{V}} \mathrm{V}$ and $\mathrm{K}-\mathrm{Ras}^{\mathrm{G} 12 \mathrm{~V}}$ expression in lung tissue, mice were infected with Adeno-Cre particles as described (23). Trametinib (Mekinist ${ }^{\circledR}$ ) was purchased from Sellek Chemicals and was administered orally daily $(1 \mathrm{mg} / \mathrm{kg})$ for 8 weeks. All mice were maintained in a mixed 129Sv/J x C57BL/6j background and housed in a barrier facility according to standards established by the European Union. All animal experiments were approved by the CNIO, the Carlos III Health Institute and the Comunidad de Madrid Ethical Committees and performed in accordance with the ARRIVE (Animal Research: Reporting on In Vivo Experiments) guidelines.

Histopathology, immunohistochemistry and SA $\boldsymbol{\beta}$-Gal staining. Tissues were fixed in $10 \%$ buffered formalin and embedded in paraffin. Hematoxilin \& Eosin (H\&E) staining and immunohistochemistry (IHC) analyses were performed on $3 \mu \mathrm{m}$ paraffin sections. For IHC, the following antibodies were used: pErk1/2 (9101, Cell Signaling Technology), Active Caspase-3 (MAB835, R\&D Systems), SPC (AB3786, Abcam), CC10 (T-18, Santa Cruz Biotechnology), CD3e (clone 145-2C11, Abcam). SA $\beta$-Gal activity in cultured MEFs as well as in cryo-sections of lungs was detected by X-Gal staining as described previously (24). 
Southern and Western blot analysis. Southern blot analysis is described in Supplementary information. Western blot analysis of protein extracts obtained from total lung tissue or MEFs was performed as described (25). Primary antibodies used included: Pan-Ras (OP40, Merck Millipore), H-Ras (clone 18, BD Transduction Labs), pErk1/2 (9101), p53 (2524), pAkt (9271), Akt (9272) [all from Cell Signaling Technology], p19Arf (clone 5-C3-1, Upstate), Erk1 (C16), p16INK4a (M-156) [all from Santa Cruz Biotechnology], GAPDH (G8795, Sigma-Aldrich).

Statistical analysis. All statistical analyses were performed using an unpaired Student's t-test. $P$ values $<0.05$ were considered to be statistically significant $(* P<0.05$, *** $P$ $<0.001)$. 


\section{RESULTS}

H-Ras and K-Ras are bioequivalent proteins. Germline ablation of K-Ras results in embryonic lethality $(6,7)$. Yet, expression of H-Ras proteins under the control of K-Ras regulatory sequences results in viable mice, thus illustrating that H-Ras can replace KRas isoforms, for most biological activities (8). Yet, these mice, designated as HrasKI, displayed dilated cardiomyopathy and arterial hypertension when they reached adulthood (8). These cardiovascular defects were initially attributed to the absence of KRas proteins in heart tissue. Subsequent studies however, revealed that germline expression of constitutively active H-Ras ${ }^{\mathrm{G} 12 \mathrm{~V}}$ led to similar cardiovascular defects in a mouse model of Costello syndrome (17). Thus, we reasoned that these cardiovascular defects might be due to H-Ras overexpression due to the presence of four H-Ras coding alleles (the knocked-in HrasKI alleles and the endogenous H-Ras alleles). To reduce the load of H-Ras expression, we crossed HrasKI mice with H-Ras ${ }^{--}$animals. HrasKI;HRas $^{-/-}$mice displayed normal heart function and hypertension (Fig. 1A and B). In addition, these mice displayed normal cardiomyocyte areas and did not accumulate fibrosis in their heart (Fig. 1C and D). These results indicate that the cardiovascular defects of HrasKI mice were due to H-Ras overexpression and not to differential activities between H-Ras and K-Ras proteins.

\section{Germline expression of the H-Ras ${ }^{\mathrm{G12V}}$ oncoprotein from the K-Ras locus results in} embryonic lethality. Next, we interrogated whether their oncogenic isoforms, K$\operatorname{Ras}^{\mathrm{G} 12 \mathrm{~V}}$ and $\mathrm{H}-\mathrm{Ras}^{\mathrm{G} 12 \mathrm{~V}}$, also have similar properties. To this end, we knocked-in a cDNA encoding an $\mathrm{H}-\mathrm{Ras}^{\mathrm{G} 12 \mathrm{~V}}$ oncogene within the first coding exon of the K-Ras locus (Fig. 2A). We also knocked-in a lox-STOP-lox (LSL) cassette upstream of the initiator codon to prevent expression of H-Ras ${ }^{\mathrm{G} 12 \mathrm{~V}}$ (Supplementary Fig. S1A-C). Expression of 
the H-Ras ${ }^{\mathrm{G} 12 \mathrm{~V}}$ cDNA clone and a genomic DNA fragment containing the four H-Ras coding exons resulted in similar expression levels indicating that the H-Ras intronic sequences do not play a significant role in regulating H-Ras expression (Fig. 2B and C). For simplicity, the wild-type $\mathrm{K}-\mathrm{Ras}^{+/+}$mice and the targeted K-Ras ${ }^{+/ \mathrm{LSLG12Vgeo}}$ and K$\operatorname{Ras}^{+/ \text {LSLH-RasG12V }}$ strains will be referred to hereafter as $K^{+}, K^{\mathrm{V} 12}$ and $K^{\mathrm{HRasV} 12}$, respectively.

Previous studies have indicated that expression of a K-Ras ${ }^{\mathrm{G} 12 \mathrm{~V}}$ oncogene in the mouse germline results in embryonic lethality (16). In contrast, expression of the H-Ras ${ }^{\mathrm{G} 12 \mathrm{~V}}$ oncogene, even in homozygosity, is well tolerated during embryonic development (17, 18). To determine whether this differential effect is an intrinsic property of the K$\operatorname{Ras}^{\mathrm{G} 12 \mathrm{~V}}$ and H-Ras ${ }^{\mathrm{G} 12 \mathrm{~V}}$ oncoproteins, we crossed $K^{\mathrm{HRas} 12}$ mice to EIIA-Cre transgenics (26) to express the H-Ras ${ }^{\mathrm{G} 12 \mathrm{~V}}$ oncoprotein from the K-Ras locus in the germline. These embryos were no longer viable and died right after implantation, a time similar to that observed for embryos expressing an endogenous K-Ras ${ }^{\mathrm{G} 12 \mathrm{~V}}$ oncoprotein (16). Hence, the ability of mice, as well as of Costello syndrome patients, to tolerate expression of an oncogenic $\mathrm{H}-\mathrm{Ras}^{\mathrm{G} 12 \mathrm{~V}}$ protein during embryonic development is dictated by the expression pattern of the H-Ras locus.

Expression of $\mathbf{H}_{-\mathbf{R a s}^{\mathbf{G}}}{ }^{\mathrm{V} \mathrm{V}}$ from the K-Ras locus in adult mice. Next, we explored the oncogenic properties of the K-Ras ${ }^{\mathrm{G} 12 \mathrm{~V}}$ and $\mathrm{H}-\mathrm{Ras}^{\mathrm{G} 12 \mathrm{~V}}$ isoforms expressed from the $\mathrm{K}$ Ras locus in adult mice. To this end, we inserted in the $K^{\mathrm{V} 12}$ and $K^{\mathrm{HRasV} 12}$ strains a transgene encoding the inducible CreERT2 recombinase under the control of the human ubiquitin C promoter (21). We exposed $K^{\mathrm{V} 12}$;hUBC-CreERT2 ${ }^{+/ \mathrm{T}}$ and $K^{\mathrm{HRasV12}}$;hUBC$\mathrm{CreERT}^{+/ \mathrm{T}}$ mice to a continuous Tmx diet to ensure efficient recombination of the 
targeted K-Ras alleles. Under these conditions, $K^{\mathrm{V} 12}$; hUBC-CreERT2 ${ }^{+/ \mathrm{T}}$ mice had a median survival of 24 weeks (Fig. 2D). In agreement with previous studies (27), these mice displayed multiple lesions in their lungs as well as abundant gastric papillomas (Fig. 2E). No other tissue displayed significant alterations at the histopathological level. $K^{\mathrm{HRasV12}}$;hUBC-CreERT2 ${ }^{+/ \mathrm{T}}$ mice submitted to the same Tmx treatment died 4 to 5 weeks earlier (Fig. 2D). These mice did not develop detectable lesions in either lungs or stomach (Fig. 2E) despite expression of the mutant H-Ras ${ }^{\mathrm{G} 12 \mathrm{~V}}$ protein in these tissues (Supplementary Fig. S1D). Instead, they displayed papillomas on their footpads after approximately 2 months of treatment (Supplementary Fig. S1E). Moreover, they had enlarged spleens and thymic tumors (Fig. 3). Tmx-treated control $K^{+}$;hUBC$\mathrm{CreERT}^{+/ \mathrm{T}}$ mice did not display detectable lesions for up to one year of age. These observations indicate that oncogenic signaling initiated by K-Ras ${ }^{\mathrm{G} 12 \mathrm{~V}}$ and H-Ras ${ }^{\mathrm{G} 12 \mathrm{~V}}$ oncoproteins expressed under the same regulatory sequences has substantially different consequences on tumor formation.

\section{Expression of H-Ras ${ }^{\mathrm{G} 2 \mathrm{~V}}$ from the K-Ras locus in adult mice induces hematopoietic}

disorders. Post-mortem characterization of Tmx-treated $K^{\mathrm{HRasV} 12} ; \mathrm{hUBC}-\mathrm{CreERT}{ }^{+/ \mathrm{T}}$ mice at humane endpoint revealed enlarged spleens infiltrated with myeloid cell populations in $100 \%$ of the animals (Fig. 3A and B). This phenotype was not observed in $K^{\mathrm{V} 12}$; $\mathrm{hUBC}-\mathrm{CreERT} 2^{+/ \mathrm{T}}$ or $K^{+}$; hUBC-CreERT2 $2^{+/ \mathrm{T}}$ mice. Flow cytometry analyses of these infiltrates revealed a dramatic expansion of $\mathrm{Grl}^{+}$and $\mathrm{Grl}^{+} / \mathrm{CD} 11 \mathrm{~b}^{+}$doublepositive cells indicative of myeloproliferative disease (MPD) (Fig. 3C and Supplementary Fig. S2A). This increase in the myeloid cell compartment was accompanied by a concomitant decrease in $\mathrm{CD}^{+} \mathrm{T}$ cells and $\mathrm{CD} 19^{+} \mathrm{B}$ cells (Supplementary Fig. S2A). Analysis of committed progenitors in the bone marrow 
(BM) of mice exposed to the Tmx diet for three months revealed a significant increase in the common myeloid progenitors (CMPs) ( $\mathrm{Lin}^{-} / \mathrm{IL} 7 \mathrm{R}^{-} / \mathrm{Sca}-1^{-} / \mathrm{c}-$ $\mathrm{Kit}^{+} / \mathrm{Fc} \mathrm{R}^{\text {low }} / \mathrm{CD} 4^{+}$) as well as a slight expansion of granulocyte-macrophage progenitor (GMP) population $\quad\left(\mathrm{Lin}^{-} / \mathrm{IL} 7 \mathrm{R} \alpha^{-} / \mathrm{Sca}-1^{-} / \mathrm{c}-\mathrm{Kit}^{+} / \mathrm{Fc} \gamma \mathrm{R}^{\mathrm{high}} / \mathrm{CD} 34^{+}\right)$ (Supplementary Fig. S2B). The common lymphoid progenitors (CLP) (Lin ${ }^{-}$ $/ \mathrm{IL} 7 \mathrm{R}^{+} / \mathrm{Sca}-1^{\text {low }} / \mathrm{c}-\mathrm{Kit}{ }^{\text {low }}$ ), the megakaryocte-erythroid progenitors (MEP) (Lin ${ }^{-}$ $/ \mathrm{IL} 7 \mathrm{R}^{-} / \mathrm{Sca}-1^{-} / \mathrm{c}-\mathrm{Kit}^{+} / \mathrm{Fc} \gamma \mathrm{R}^{\text {low }} / \mathrm{CD} 34^{-}$) and LSK cells $\left(\mathrm{Lin}^{-} / \mathrm{Sca}-1^{+} / \mathrm{c}-\mathrm{Kit}^{+}\right)$, a population enriched in hematopoietic stem cells, did not display significant changes. These observations indicate that $\mathrm{H}-\mathrm{Ras}{ }^{\mathrm{G} 12 \mathrm{~V}}$ but not $\mathrm{K}-\mathrm{Ras}^{\mathrm{G}}{ }^{\mathrm{G} 2 \mathrm{~V}}$ is capable of inducing MPD in adult mice via expansion of a specific subset of committed progenitors in their BM.

We also detected large tumor masses in the thymus in over $85 \%$ of $K^{\mathrm{HRasV12}}$,hUBC$\mathrm{CreERT}^{+/ \mathrm{T}}$ animals, a pathology not observed in $K^{\mathrm{V} 12}$; hUBC-CreERT2 $2^{+/ \mathrm{T}}$ or $K^{+}$; hUBC$\mathrm{CreERT}^{+/ \mathrm{T}}$ mice (Fig. 3D). Histopathological characterization revealed the presence of T cell lymphoblastic lymphoma (T-ALL), as determined by a uniform expansion of $\mathrm{CD}^{+} \mathrm{T}$ lymphocytes. Moreover, tumors displayed an increase in double negative (DN) CD4/CD8 ${ }^{-}$, single positive $\mathrm{CD}^{+}$and single positive $\mathrm{CD}^{+}$cells (Fig. 3E). In particular, when DN cells were further characterized, we detected elevated DN1 $\left(\mathrm{CD} 44^{+} / \mathrm{CD} 25^{-}\right)$ and DN2 $\left(\mathrm{CD} 44^{+} / \mathrm{CD} 25^{+}\right)$populations (Supplementary Fig. S3A). The characteristic hyperactivation of the Notch pathway in T-ALL was also observed as demonstrated by immunostaining of Hes1 (28) (Supplementary Fig. S3B). We also detected abundant lymphocyte infiltrates in a variety of organs including lung, liver, kidney and eye (Supplementary Fig. S3C). These data indicate that in addition to MPD, most mice expressing the H-Ras ${ }^{\mathrm{G} 12 \mathrm{~V}}$ oncoprotein from the K-Ras locus also developed T-ALL, a tumor type not induced by the K-Ras ${ }^{\mathrm{G} 12 \mathrm{~V}}$ isoform. 


\section{H-Ras ${ }^{G 12 V}$ driven from the $K$-Ras locus induces pancreatic tumors. Expression of a} resident $\mathrm{K}-\mathrm{Ras}^{\mathrm{G} 12 \mathrm{~V}}$ oncogene during late embryonic development in pancreatic acinar cells results in pancreatic intraepithelial neoplasias (PanIN lesions) that occasionally progress to pancreatic ductal adenocarcinomas (PDAC) (22). No such lesions were observed in $\mathrm{H}-\mathrm{Ras}^{+/ \mathrm{G} 12 \mathrm{~V}}$ or H-Ras ${ }^{\mathrm{G} 12 \mathrm{~V} / \mathrm{G} 12 \mathrm{~V}}$ mice in which the H-Ras ${ }^{\mathrm{G} 12 \mathrm{~V}}$ oncoprotein is expressed from its own locus (17). To determine whether H-Ras ${ }^{\mathrm{G} 12 \mathrm{~V}}$ could induce pancreatic lesions when expressed from the K-Ras locus, we crossed $K^{\mathrm{HRasV12}}$ mice to Elas-tTA/tetO-Cre transgenic animals known to selectively express Cre recombinase in acinar cells from E16.5 onwards (22). Analysis of serial pancreatic tissue sections of $K^{\mathrm{HRasV12}} ;$ Elas-tTA/tetO-Cre animals at one year of age revealed the appearance of focal low and high-grade PanIN lesions indistinguishable from those present in $K^{\mathrm{V} 12}$;ElastTA/tetO-Cre mice (Supplementary Fig. S4A). However, the number of lesions was significantly lower than in similar mice expressing the K-Ras ${ }^{\mathrm{G} 12 \mathrm{~V}}$ oncoprotein (Fig. 4A).

Loss of the p53 tumor suppressor p53 accelerated tumor formation in $K^{\mathrm{HRaV} 12}$;ElastTA/tetO-Cre animals (22). These mice died of PDAC tumors although they survived longer than those mice expressing the K-Ras ${ }^{\mathrm{G} 12 \mathrm{~V}}$ oncoprotein (30 vs. 17 weeks average survival, a 75\% increase) (Fig. 4B and Supplementary Fig. S4A). Comparative analysis of $K^{\mathrm{HRasV} 12} ; \mathrm{p} 53^{\text {lox/lox}} ;$ Elas-tTA/tetO-Cre and $K^{\mathrm{V} 12} ; \mathrm{p} 53^{\text {lox/lox }} ;$ Elas-tTA/tetO-Cre mice at 10 weeks of age revealed that the H-Ras ${ }^{\mathrm{G} 12 \mathrm{~V}}$ expressing animals displayed significantly fewer PanIN lesions and PDAC tumors than those expressing K-Ras ${ }^{\mathrm{G} 12 \mathrm{~V}}$ (Fig. 4C). These quantitative differences are likely to be due to a reduction in the number of initiating events since the number of acinar-ductal metaplasias (ADM) was significantly 
higher in acinar cell explants of $K^{\mathrm{V} 12}$ mice than in those derived from $K^{\mathrm{HRasV} 12}$ animals (Fig. 4D and Supplementary Fig. S4B).

\section{H-Ras ${ }^{G 12 V}$ failed to induce lung adenocarcinomas due to excessive MAPK}

signaling. Systemic expression of H-Ras ${ }^{\mathrm{G} 12 \mathrm{~V}}$ from the K-Ras locus did not yield lung lesions including hyperplasias or benign adenomas. To rule out non-cell autonomous effects, we infected $K^{\mathrm{HRasV} 12}$ and $K^{\mathrm{V} 12}$ mice with Adeno-Cre particles to selectively induce oncogene expression in lung tissue. Six months after infection, none of the $K^{\mathrm{HRasV} 12}$ mice displayed detectable lesions in their lungs, whereas all $K^{\mathrm{V} 12}$ animals had developed multiple lesions including lung adenocarcinomas (Supplementary Fig. S4C and S4D).

Tmx treatment of $K^{\mathrm{V} 12}$;hUBC-CreERT2 ${ }^{+/ \mathrm{T}}$ and $K^{\mathrm{HRasV12}}$;hUBC-CreERT2 ${ }^{+/ \mathrm{T}}$ mice for short periods of time allowed us to analyze the immediate events that followed expression of the K-Ras ${ }^{\mathrm{G} 12 \mathrm{~V}}$ and H-Ras ${ }^{\mathrm{G} 12 \mathrm{~V}}$ oncoproteins in lung tissue. Four days after Tmx treatment, H-Ras ${ }^{\mathrm{G} 12 \mathrm{~V}}$ induced phosphorylation of the downstream Erk1/2 kinases (pErk $1 / 2)$ in over $20 \%$ of the cells, whereas expression of $\mathrm{K}-\mathrm{Ras}^{\mathrm{G} 12 \mathrm{~V}}$ only resulted in pErk1/2 immunostaining in less than $5 \%$ of the cells (Fig. 5A). Similar results were obtained seven days after treatment. These findings were not due to a differential number of cells expressing the K-Ras ${ }^{\mathrm{G} 12 \mathrm{~V}}$ and H-Ras ${ }^{\mathrm{G} 12 \mathrm{~V}}$ oncoproteins since the levels of Cre-mediated recombination in the lungs of $K^{\mathrm{V} 12} ; \mathrm{hUBC}-\mathrm{CreERT} 2^{+/ \mathrm{T}}$ and $K^{\mathrm{HRasV12}} ;$ hUBC-CreERT2 ${ }^{+/ \mathrm{T}}$ mice were similar (Supplementary Fig. S4E and S4F). More importantly, when mice were analyzed two weeks after Tmx treatment, the number of $\mathrm{pErk} 1 / 2$ expressing cells in the lungs of $K^{\mathrm{HRasV} 12}$ mice decreased dramatically whereas those present in $K^{\mathrm{V} 12}$ lungs displayed a modest increase (Fig. 5A). These 
results were further confirmed by Western blot analysis (Fig. 5B). These observations were selective for lung cells since we did not observe significantly differential numbers of pErk expressing cells in other tissues with the possible exception of cells in the basal layer of the skin and in the white pulp of the spleen (Supplementary Fig. S5A). To determine whether these results were due to differential expression levels of the two mutant proteins, we compared their relative levels of expression in the lungs of

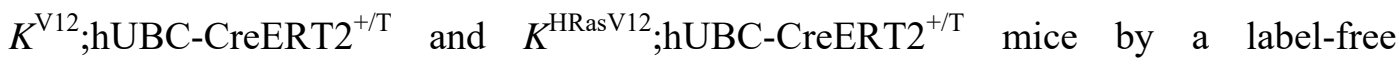
quantification approach (29). This technique allowed us to determine their relative amounts based on the detection of the shared peptide (6-LVVVGAVGVGK-16) in which the underlined residue corresponds to the activating valine (Supplementary Fig. S5B). As illustrated in Fig. 5C, H-Ras ${ }^{\mathrm{G} 12 \mathrm{~V}}$ is expressed at about 5-fold higher levels than K-Ras ${ }^{\mathrm{G} 12 \mathrm{~V}}$. The higher levels of $\mathrm{H}-\mathrm{Ras}^{\mathrm{G}}{ }^{\mathrm{G} 2 \mathrm{~V}}$ expression also resulted in increased levels of total GTP-bound active Ras complexes as determined by RBD pull down assays (Fig. 5D).

Next, we examined whether the increased levels of GTP-bound H-Ras ${ }^{\mathrm{G} 12 \mathrm{~V}}$ may have an effect on the proliferation of $\mathrm{H}-\mathrm{Ras}^{\mathrm{G} 12 \mathrm{~V}}$ expressing cells that might prevent the appearance of hyperplastic lesions. To this end, we used the recombinant $\mathrm{K}-$ Ras $^{\mathrm{H}-\mathrm{RasG} 12 \mathrm{~V}}$ allele as a molecular marker for the presence of H-Ras ${ }^{\mathrm{G} 12 \mathrm{~V}}$ expressing lung cells. Exposure of 4-week old $K^{\mathrm{HRasV12}}$,hUBC-CreERT2 ${ }^{+/ \mathrm{T}}$ mice to a Tmx diet for four weeks resulted in the effective recombination of the K-Ras ${ }^{\text {LSLH-RasG12V }}$ allele, thus indicating that a significant fraction of lung cells expressed the H-Ras ${ }^{\mathrm{G} 12 \mathrm{~V}}$ oncoprotein (Fig. 6A). However, when these $K^{\mathrm{HRasV12}}$;hUBC-CreERT2 ${ }^{+/ \mathrm{T}}$ mice were maintained in a diet lacking Tmx for an additional 8 week period, those cells that contained the recombined K-Ras ${ }^{\mathrm{H}-\mathrm{RasG} 12 \mathrm{~V}}$ allele diagnostic of H-Ras ${ }^{\mathrm{G} 12 \mathrm{~V}}$ expression completely disappeared (Fig. 
$6 \mathrm{~A})$. These results were selective for lung cells since the $\mathrm{K}-\mathrm{Ras}^{\mathrm{H}-\mathrm{RasG12V}}$ recombined allele remains present in other tissues such as thymus, after the 8 week period in the absence of Tmx (Fig. 6A). To determine whether the disappearance of the lung cells was due to excessive H-Ras ${ }^{\mathrm{G} 12 \mathrm{~V}}$ signaling, we treated $K^{\mathrm{HRasV} 12}$; hUBC-CreERT2 ${ }^{+/ \mathrm{T}}$ mice with a non-limiting dose $(1 \mathrm{mg} / \mathrm{kg})$ of Trametinib, a MEK inhibitor known to effectively block MAPK signaling driven by Ras oncogenes (30). Trametinib was provided during the 8 weeks in which mice were no longer exposed to Tmx. As illustrated in Fig. 6A, these mice retained the $\mathrm{K}-\mathrm{Ras}^{\mathrm{H}-\mathrm{RasG} 12 \mathrm{~V}}$ recombined allele indicating that expression of the H-Ras ${ }^{\mathrm{G} 12 \mathrm{~V}}$ oncoprotein was no longer deleterious for lung cells in the presence of the MEK inhibitor.

\section{H-Ras $^{\text {G12V }}$ expression in lung cells induces a senescence-like arrest partially}

mediated by p53. The disappearance of $\mathrm{H}-\mathrm{Ras}^{\mathrm{G} 12 \mathrm{~V}}$ expressing lung cells was not due to apoptosis since we could not detect increased levels of Caspase 3 in the lungs of Tmxtreated $K^{\mathrm{HRasV12}}$ mice (Supplementary Fig. S5C). Likewise, we did not detect senescence-associated $\beta$-galactosidase (SA- $\beta \mathrm{Gal}$ ) expression, a standard marker for oncogene-induced senescence (OIS). Yet, we observed the induction of other senescence markers such as p16Ink4a and p19Arf (Fig. 5B and 6B). These results suggest that H-Ras ${ }^{\mathrm{G} 12 \mathrm{~V}}$ expression may induce some sort of non-canonical senescencelike state. Finally, we interrogated whether this phenomenon could be mediated by p53. To this end, we introduced $p 53^{\text {lox }}$ alleles into $K^{\mathrm{V} 12}$ and $K^{\mathrm{HRasV} 12}$ mice. As illustrated in Supplementary Fig. S6A and S6B, $K^{\mathrm{HRasV} 12} ; p 53^{\text {lox/lox }}$ mice developed some hyperplasias and occasional adenomas in $30 \%$ of the animals, all of which stained positive for type II alveolar cell markers (Supplementary Fig. S6C). These results indicate that induction of 
a senescence-like phenotype in lung tissue by expression of the H-Ras ${ }^{\mathrm{G} 12 \mathrm{~V}}$ oncoprotein from the K-Ras locus is only partially mediated by $\mathrm{p} 53$.

\section{H-Ras ${ }^{G 12 V}$ expressed from the K-Ras locus induces OIS in mouse embryonic}

fibroblasts. Finally, we decided to compare the effect of expressing the K-Ras ${ }^{\mathrm{G} 12 \mathrm{~V}}$ and $\mathrm{H}-\mathrm{Ras}^{\mathrm{G} 12 \mathrm{~V}}$ oncoproteins from the same K-Ras locus in mouse embryonic fibroblasts (MEFs). Previous studies have shown that overexpression of these oncoproteins in MEFs readily induced OIS (31). However, when they were expressed from their own endogenous promoters, they failed to induce OIS $(16,17)$. We induced expression of either K-Ras ${ }^{\mathrm{G} 12 \mathrm{~V}}$ or $\mathrm{H}-\mathrm{Ras}^{\mathrm{G} 12 \mathrm{~V}}$ oncoproteins by infecting immortalized $K^{\mathrm{V} 12}$ and $K^{\mathrm{HRasV12}}$ MEFs with Adeno-Cre particles, respectively. As expected, K-Ras ${ }^{\mathrm{G} 12 \mathrm{~V}}$ expression did not cause significant changes in downstream signaling (Fig. 7A). In contrast, expression of $\mathrm{H}-\mathrm{Ras}{ }^{\mathrm{G} 12 \mathrm{~V}}$ resulted in a sustained increase in the phosphorylation of the downstream substrates pErk and pAkt (Fig. 7A). Moreover, whereas K-Ras ${ }^{\text {G12V }}$ expression had no detectable effects on proliferation, expression of $\mathrm{H}-\mathrm{Ras}^{\mathrm{G}}{ }^{\mathrm{G}} \mathrm{V}$ effectively induced OIS leading to complete cessation of cell proliferation and SA- $\beta$ Gal expression (Fig. 7B and C).

H-Ras ${ }^{\text {G12V }}$ expressing MEFs displayed increased levels of p53 (Fig. 7A). Yet, efficient depletion of p53 by small-hairpin RNAs had no effect on cell cycle arrest or induction of senescence, indicating that abrogation of p53 expression was not sufficient to overcome H-Ras ${ }^{\mathrm{G} 12 \mathrm{~V}}$-induced OIS (Supplementary Fig. S7A-C). Likewise, we observed no significant increase in the expression levels of p16INK4a. However, ectopic expression adenoviral E1A, an oncoprotein known to target the p53 and $\mathrm{Rb}$ pathways (32), we were able to bypass OIS and restored efficient proliferation of MEFs (Fig. 7B 
and C and Supplementary Fig. S7D). Furthermore, E1A cooperated with H-Ras ${ }^{\text {G12V }}$, but not with K-Ras ${ }^{\mathrm{G} 12 \mathrm{~V}}$, to transform immortal MEFs (Figs. 7D and Supplementary Fig. S7E). In an effort to provide a mechanistic explanation for the dramatic differential effects induced by the K-Ras ${ }^{\mathrm{G} 12 \mathrm{~V}}$ versus the H-Ras ${ }^{\mathrm{G} 12 \mathrm{~V}}$ oncoproteins when expressed from the same locus, we established their relative levels of expression using label-free quantification techniques. As illustrated in Fig. 7E, H-Ras ${ }^{\mathrm{G} 12 \mathrm{~V}}$ was more efficiently expressed (about 2.5-fold) than K-Ras ${ }^{\mathrm{G} 12 \mathrm{~V}}$.

To determine whether these minor differences might be responsible for the drastically differential outputs, we decided to explore how differential expression levels of the same oncoprotein, H-Ras ${ }^{\mathrm{G} 12 \mathrm{~V}}$, affected the biological behavior of MEFs. Whereas HRas $^{\mathrm{G} 12 \mathrm{~V}}$ expressed from its own promoter had no effect of MEF properties including immortalization, proliferation or senescence (17), H-Ras ${ }^{\mathrm{G} 12 \mathrm{~V}}$ expression from the K-Ras promoter in $K^{\mathrm{HRasV} 12}$ led to rapid OIS (Fig. 7B and C). Western blot analysis revealed that the amount of H-Ras protein (both H-Ras and H-Ras ${ }^{\mathrm{G} 12 \mathrm{~V}}$ ) in $K^{\mathrm{HRasV12}}$ MEFs was 3 fold higher than in H-Ras ${ }^{\mathrm{G} 12 \mathrm{~V} / \mathrm{G} 12 \mathrm{~V}}$ MEFs (Fig. 7F). Since $K^{\mathrm{HRasV} 12}$ MEFs also express a wild-type $\mathrm{H}-\mathrm{Ras}$ protein from its endogenous locus, the amount of $\mathrm{H}-\mathrm{Ras}{ }^{\mathrm{G} 12 \mathrm{~V}}$ expressed from the $\mathrm{K}$-Ras locus in $\mathrm{K}^{\mathrm{HRasV12}}$ MEFs compared to that expressed from its own locus in $\mathrm{H}-\mathrm{Ras}^{\mathrm{G} 12 \mathrm{~V} / \mathrm{G} 12 \mathrm{~V}}$ MEFs is a mere 2-fold higher $(1.9 \pm 0.7)$ than that expressed from its own locus. These observations establish that relatively subtle increases in the levels of expression of the H-Ras ${ }^{\mathrm{G} 12 \mathrm{~V}}$ oncoprotein can result in dramatically different biological consequences. 


\section{DISCUSSION}

Early genetic studies revealed that the three Ras loci have different biological properties. Whereas K-Ras is essential for embryonic development, H-Ras and N-Ras are dispensable (5-7). To determine whether these differences are due to the intrinsic properties of the different Ras protein isoforms or to their pattern of expression, Potenza et al. modified the endogenous K-Ras alleles so they direct the synthesis of H-Ras instead of K-Ras proteins (8). These mice developed to adulthood indicating that H-Ras could effectively compensate for the absence of the K-Ras proteins. Yet, these mice displayed cardiovascular defects including dilated cardiomyopathy associated with arterial hypertension, attributed to the lack of K-Ras proteins in heart tissue (8). However, as illustrated in this study, these cardiovascular defects were a direct consequence of the overexpression of H-Ras proteins, since these mice carry four H-Ras expressing alleles, two endogenous H-Ras alleles and two HrasKI alleles. Indeed, elimination of the endogenous H-Ras alleles completely prevented these cardiovascular defects. Moreover, HrasKI;H-Ras ${ }^{-/-}$mice appear to be completely normal, indicating that the H-Ras and K-Ras proteins are fully bioequivalent, at least under normal homeostatic conditions. These observations are surprising considering the different properties of the H-Ras and K-Ras proteins in subcellular transport, posttranslational processing and localization within the plasma membrane $(3,4)$. Whether their differential properties may play a role under stress conditions remains to be determined.

The intense focus on RAS biology is due, at least in part, to their involvement in human cancer. Over the years, scientists have been baffled by the distinct incidence of the various RAS oncogenes in tumors (9). In an attempt to shed some light on this issue, we expanded the early work of Potenza et al. (8), by generating a new conditional mouse 
strain, $K^{\mathrm{HRasV} 12}$, that expresses the H-Ras ${ }^{\mathrm{G} 12 \mathrm{~V}}$ oncoprotein from the endogenous K-Ras locus. Germline expression of $\mathrm{H}-\mathrm{Ras}^{\mathrm{G}}{ }^{\mathrm{V} V}$ from its own locus had no significant effect on embryonic development. Yet, these animals displayed facial and cardiovascular defects reminiscent of patients with Costello syndrome $(17,18)$. However, germline expression of H-Ras ${ }^{\mathrm{G} 12 \mathrm{~V}}$ from the endogenous K-Ras locus led to early embryonic death at a time similar to that observed for embryos expressing an endogenous K-Ras ${ }^{\mathrm{G} 12 \mathrm{~V}}$ oncoprotein (16). Thus, expression of K-Ras and H-Ras oncoproteins from the K-Ras locus is equally deleterious for embryonic development. These observations illustrate that the viability of $\mathrm{H}-\mathrm{Ras}^{+/ \mathrm{G} 12 \mathrm{~V}}$ and $\mathrm{H}-\mathrm{Ras}^{\mathrm{G} 12 \mathrm{~V} / \mathrm{G} 12 \mathrm{~V}}$ mice must be due to a more restricted pattern of expression, lower expression levels or a combination of both $(17,18)$.

Expression of K-Ras ${ }^{\mathrm{G} 12 \mathrm{~V}}$ in embryonic acinar cells resulted in the formation of low and high-grade PanIN lesions and occasional PDAC tumors (24). Expression of the H$\operatorname{Ras}^{\mathrm{G} 12 \mathrm{~V}}$ oncoprotein from the K-Ras locus also resulted in the formation of low and high-grade PanIN lesions albeit at lower frequencies, with no detectable PDAC tumors, at least by one year of age. Whether the high-grade PanINs will eventually progress to yield PDAC tumors in older animals remains to be determined. Recent studies have indicated that K-Ras ${ }^{\mathrm{G} 12 \mathrm{~V}}$ but not $\mathrm{H}-\mathrm{Ras}^{\mathrm{G} 12 \mathrm{~V}}$ promotes tumor formation by suppressing non-canonical Wnt signaling (33). This property was used to repress the transforming activity of K-Ras ${ }^{\mathrm{G} 12 \mathrm{~V}}$ in pancreatic xenograft tumor models with prostratin, a PKC activator (33). It will be interesting to explore whether this natural product has differential activity in pancreatic lesions driven by $\mathrm{K}-\mathrm{Ras}^{\mathrm{G} 12 \mathrm{~V}}$ and $\mathrm{H}-\mathrm{Ras}^{\mathrm{G} 12 \mathrm{~V}}$ oncoproteins. 
Ubiquitous expression of H-Ras ${ }^{\mathrm{G} 12 \mathrm{~V}}$ in adult $K^{\mathrm{HRasV} 12}$ mice led to a variety of tumors, mainly papillomas and hematopoietic malignancies. More importantly, the pattern of tumors observed in these mice was significantly different to that present in $K^{\mathrm{V} 12}$ animals, thus indicating that $\mathrm{H}-\mathrm{Ras}^{\mathrm{G} 12 \mathrm{~V}}$ and $\mathrm{K}-\mathrm{Ras}^{\mathrm{G} 12 \mathrm{~V}}$ oncoproteins have different transforming capabilities in different tissues. Tmx-treated adult $K^{\mathrm{HRasV12}}$;hUBC$\mathrm{CreERT}^{+/ \mathrm{T}}$ mice developed hematological malignancies not observed in $K^{\mathrm{V} 12}$; $\mathrm{hUBC}$ $\mathrm{CreERT}^{+/ \mathrm{T}}$ animals, including MPD, a disease that resulted from expansion of the CMP population, as well as T-ALL. Previous studies have reported that expression of a resident $\mathrm{K}-$ Ras $^{\mathrm{G} 12 \mathrm{D}}$ oncogene in the hematopoietic compartment caused fatal MPD (34, 35) as well as T-ALL upon BM transplantation (36). In these studies, however, K$\operatorname{Ras}^{\mathrm{G} 12 \mathrm{D}}$ expression was induced by an Mx1-Cre transgene known to express low levels of Cre recombinase activity during embryonic development. Thus, it is possible that these different results might be due to the differential susceptibility of embryonic hematopoietic precursors to K-Ras oncoproteins.

On the contrary, some tissues are susceptible to K-Ras ${ }^{\mathrm{G} 12 \mathrm{~V}}$, but not to H-Ras ${ }^{\mathrm{G} 12 \mathrm{~V}}$ induced neoplastic lesions such as the lung alveoli and the stomach epithelium. The lack of lung tumors in $K^{\mathrm{HRasV12}}$ mice appears to be a consequence of overactivation of the MAPK signaling cascade by the H-Ras ${ }^{\mathrm{G} 12 \mathrm{~V}}$ oncoprotein. Indeed, H-Ras ${ }^{\mathrm{G} 12 \mathrm{~V}}$ expression in type II alveolar cells of $K^{\mathrm{HRasV12}}$ mice induced a significantly more robust phosphorylation of the Erk kinases than that observed upon induction of the K-Ras ${ }^{\mathrm{G} 12 \mathrm{~V}}$ oncoprotein in $K^{\mathrm{V} 12}$ animals. This increased signaling induced a non-canonical, senescent-like state that prevented proliferation of the $\mathrm{H}-\mathrm{Ras}{ }^{\mathrm{G} 12 \mathrm{~V}}$-expressing lung alveolar cells. Ablation of $\mathrm{p} 53$ in $K^{\mathrm{HRasV12}}$ mice resulted in limited induction of hyperplastic lesions along with few adenomas, but not in overt lung tumor development. 
Thus, indicating that the senescent-like state was only partially mediated by $\mathrm{p} 53$. These senescent $\mathrm{H}-\mathrm{Ras}^{\mathrm{G} 12 \mathrm{~V}}$ expressing cells are short lived since they could no longer be detected eight weeks after induction of $\mathrm{H}-\mathrm{Ras}^{\mathrm{G} 12 \mathrm{~V}}$ expression. Likewise, IHC examination of lung tissue of $K^{\mathrm{HRasV} 12}$ mice two weeks after induction of H-Ras ${ }^{\mathrm{G} 12 \mathrm{~V}}$ expression revealed a drastic reduction in the number of pErk-positive cells. The fate of these cells remains unclear, although the absence of active Caspase 3 expression suggests that they did not undergo apoptosis. Finally, exposure of $K^{\mathrm{HRasV12}}$ mice to the MEK inhibitor Trametinib prevented elimination of the H-Ras ${ }^{\mathrm{G} 12 \mathrm{~V}}$ expressing cells. Thus providing further evidence that the senescent-like state of these H-Ras ${ }^{\mathrm{G} 12 \mathrm{~V}}$ expressing lung cells was due to excessive MAPK signaling.

It has been proposed that the abundance of Ras isoforms can be affected by differences in protein translation efficiency (37). K-Ras mRNA is less efficiently translated than HRas due to the preferential usage of rare codons (37). Germline replacement of rare codons in the K-Ras locus resulted in mice that expressed higher levels of K-Ras proteins (38). Interestingly, these mice displayed increased resistance to urethanemediated carcinogenesis, suggesting that increased levels of K-Ras oncoproteins had adverse effects on lung tumorigenesis (38). Whether these observations were due to the induction of a senescent-like state as described here for the H-Ras ${ }^{\mathrm{G} 12 \mathrm{~V}}$ oncoprotein, remains to be determined. Precise quantitative analysis of the relative amounts of $\mathrm{H}$ $\operatorname{Ras}^{\mathrm{G} 12 \mathrm{~V}}$ and K-Ras ${ }^{\mathrm{G} 12 \mathrm{~V}}$ proteins in lung tissue revealed that $\mathrm{H}-\mathrm{Ras}{ }^{\mathrm{G} 12 \mathrm{~V}}$ was present at 5fold higher levels than K-Ras ${ }^{\mathrm{G} 12 \mathrm{~V}}$. Thus, it is possible that these oncoproteins may have similar signaling properties and their differential effects in lung tissue could be primarily due to quantitative differences in their levels of expression. Whether the differential results obtained in hematopoietic cells in which only $\mathrm{H}-\mathrm{Ras}{ }^{\mathrm{G} 12 \mathrm{~V}}$ was capable 
of inducing tumors is also due to quantitative differences remains to be determined. For instance, it is possible that the hematopoietic precursors responsible for initiating MPD and T-ALL may require higher levels of MAP kinase signaling such as those provided by $\mathrm{H}-\mathrm{Ras}^{\mathrm{G} 12 \mathrm{~V}}$ expression. Yet, at this time, we cannot rule out that the H-Ras ${ }^{\mathrm{G} 12 \mathrm{~V}}$ and K-Ras ${ }^{\mathrm{G} 12 \mathrm{~V}}$ oncoproteins may utilize differential signaling pathways in these hematopoietic cells.

Previous studies have illustrated the presence of H-Ras oncogenes in lung tumors of HrasKI mice exposed to urethane (39). Indeed, these mice developed more lung tumors than wild-type animals exposed to the same carcinogenic insult, a result attributed to the frequent activation of H-Ras oncogenes (39). This apparent conundrum could be explained by the presence of lower levels of H-Ras protein in HrasKI mice. Indeed, HrasKI is a chimeric allele made of H-Ras and K-Ras sequences that contains K-Rasderived rare codons in two of the four coding exons. This fact may result in limited translation efficiency $(9,36,37)$. Thus, HrasKI mice may express lower levels of H-Ras as compared to those present in $K^{\mathrm{HRasV} 12}$ animals that exclusively use H-Ras-derived codons. Alternatively, urethane may induce mutations and/or epigenetic alterations that prevent the development of the senescent-like state induced by H-Ras ${ }^{\mathrm{G} 12 \mathrm{~V}}$ expression in $K^{\mathrm{HRasV12}}$ mice.

Finally, in vitro studies also provided strong support for a direct relationship between $\mathrm{H}-\mathrm{Ras}^{\mathrm{G} 12 \mathrm{~V}}$ and K-Ras ${ }^{\mathrm{G} 12 \mathrm{~V}}$ induced MAPK signaling and biological output. Expression of a resident K-Ras ${ }^{\mathrm{G} 12 \mathrm{~V}}$ oncoprotein in primary MEFs led to immediate immortalization bypassing the replication-induced senescence characteristic of wild-type cells (16). In contrast, of the H-Ras ${ }^{\mathrm{G} 12 \mathrm{~V}}$ oncoprotein form the K-Ras locus resulted in canonical OIS 
leading to complete cessation of cell proliferation and expression of SA- $\beta$ Gal. This senescence phenotype was accompanied by a robust increase in the phosphorylation of Erk1/2 and Akt. Quantitative analysis of the relative levels of expression of the H$\operatorname{Ras}^{\mathrm{G} 12 \mathrm{~V}}$ and K-Ras ${ }^{\mathrm{G} 12 \mathrm{~V}}$ oncoproteins in $K^{\mathrm{HRasV} 12}$ and $K^{\mathrm{V} 12}$ MEFs, respectively, revealed 2.5-fold higher levels of expression of H-Ras ${ }^{\mathrm{G} 12 \mathrm{~V}}$. Thus, raising the possibility that differences other than levels of expression may account for the differential biological outputs induced by these oncoproteins. However, comparative analysis of the levels of expression of H-Ras ${ }^{\mathrm{G} 12 \mathrm{~V}}$ in $\mathrm{K}^{\mathrm{HRasV} 12}$ MEFs in which induces irreversible OIS versus H$\operatorname{Ras}^{\mathrm{G} 12 \mathrm{~V} / \mathrm{G} 12 \mathrm{~V}}$ MEFs in which there are no significant biological changes revealed a meager 2-fold difference in its levels of expression. Thus, minor changes in the levels of expression of the H-Ras ${ }^{\mathrm{G} 12 \mathrm{~V}}$ oncoprotein can induce significantly different outputs. These results, taken together, underscore the need to better understand the molecular mechanisms that regulate the intensity of MAPK signaling in order to control the detrimental effects induced by Ras oncoproteins during neoplastic development.

It is difficult to reckon why the wild-type H-Ras and K-Ras isoforms are bioequivalent in spite of their differential properties relating to cellular trafficking, post-translational processing and subcellular localization, whereas their oncogenic counterparts display differential transforming properties. It is conceivable that cells tolerate an ample range of Ras signaling during normal homeostasis providing that the differential signaling intensities between the different Ras isoforms stay below a critical threshold. In contrast, elevated signaling induced by Ras oncoproteins may activate "emergency" signals that either result in activation of negative feedback loops or in induction of OIS ultimately leading to cell death. Activation of OIS and/or feedback loops might be cell type dependent, leading to the manifestation of different phenotypes ranging from 
senescence to malignant transformation. Finally, it should be noted that our observations do not eliminate the possibility that different oncogenic Ras isoforms may also engage differential signaling pathways. Understanding the differential outputs of H-Ras and K-Ras oncogenes in different cell types will require a more precise knowledge of the molecular mechanisms that control their key effector pathways. Research. 


\section{Acknowledgements}

We thank Alan Balmain (UCSF) for stimulating discussions and for critically reading the manuscript. We also thank Marta San Roman, Raquel Villar, Beatriz Jiménez, Nuria Cabrera, Patricia Villanueva and Jennifer Condo for excellent technical assistance. We value the support of Juan Antonio Cámara and Francisca Mulero (Molecular Imaging Core Unit, CNIO) for the echocardiographic analyses, Alba de Martino (Histopathology Core Unit, CNIO) for her help with mouse histopathology as well as Eduardo Zarzuela and Javier Muñoz (Proteomics Core Unit, CNIO) for mass spectrometric analyses.

\section{Grant support}

This work was supported by grants from the European Research Council (ERC-AG/ 250297-RAS AHEAD), EU-Framework Programme (LSHG-CT-2007037665/CHEMORES, HEALTH-F2-2010-259770/LUNGTARGET and HEALTH2010-260791/EUROCANPLATFORM), Spanish Ministry of Economy and Competitiveness (SAF2011-30173 and SAF2014-59864-R) and Autonomous Community of Madrid (S2011/BDM-2470/ONCOCYCLE) to MB, Castilla-León Autonomous Government (CSI101U13, BIO/SA01/15), the Spanish Ministry of Economy and Competitiveness (SAF2012-31371, RD12/0036/0002), Worldwide Cancer Research (14-1248), the Solórzano Foundation, and the Ramón Areces Foundation to XRB. Spanish government-sponsored funding to XRB is partially supported by the European Regional Development Fund. MB is the recipient of an Endowed Chair from the AXA Research Fund. 


\section{REFERENCES}

1. Malumbres M, Barbacid M. RAS oncogenes: the first 30 years. Nat Rev Cancer 2003;3:459-465.

2. Karnoub AE, Weinberg RA. Ras oncogenes: split personalities. Nat Rev Mol Cell Biol 2008;9:517-531.

3. Cox AD, Der CJ, Philips MR. Targeting RAS membrane association: back to the future for anti-RAS drug discovery? Clin Cancer Res 2015;21:1819-1827.

4. Prior IA, Hancock JF. Ras trafficking, localization and compartmentalized signalling. Semin Cell Dev Biol 2012;23:145-153.

5. Esteban LM, Vicario-Abejón C, Fernández-Salguero P, Fernández-Medarde A, Swaminthan N, Yienger K, et al. Targeted genomic disruption of H-ras and N-ras, individually or in combination, reveals the dispensability of both loci for mouse growth and development. Mol Cell Biol 2001;21:1444-1452.

6. Johnson L, Greenbaum D, Cichowski K, Mercer K, Murphy E, Schmitt E, et al. Kras is an essential gene in the mouse with partial functional overlap with N-ras. Genes Dev 1997;11:2468-2481.

7. Koera K, Nakamura K, Nakao K, Miyoshi J, Toyoshima K, Hatta T, et al. K-ras is essential for the development of the mouse embryo. Oncogene 1997;15:1151-1159.

8. Potenza N, Vecchione C, Notte A, De Rienzo A, Rosica A, Bauer L, et al. Replacement of K-Ras with H-ras supports embryonic development despite inducing cardiovascular pathology in adult mice. EMBO Rep 2005;6:432-437.

9. Prior IA, Lewis PD, Mattos CA. A comprehensive survey of Ras mutations in cancer. Cancer Res 2012;72:2457-2467.

10. Tidyman WE, Rauen KA. The RASopathies: developmental syndromes of Ras/MAPK pathway dysregulation. Curr Opin Genet Dev 2009;19(3):230-236. 
11. Aoki Y, Niihori T, Inoue S, Matsubara Y. Recent advances in RASopathies. J Hum Genet 2016;61:33-39.

12. Gripp KW, Lin AE. Costello syndrome: a Ras/mitogen activated protein kinase pathway syndrome (rasopathy) resulting from HRAS germline mutations. Genet Med 2012;14:285-292.

13. Aoki Y, Niihori T, Kawame H, Kurosawa K, Ohashi H, Tanaka Y, et al. Germline mutations in HRAS proto-oncogene cause Costello syndrome. Nat Genet 2005;37:1038-1040.

14. Kratz CP, Schubbert S, Bollag G, Niemeyer CM, Shannon K, Zenker M. Germline mutations in components of the Ras signaling pathway in Noonan syndrome and related disorders. Cell Cycle 2006;5:1607-1611.

15. Tuveson DA, Shaw AT, Willis NA, Silver DP, Jackson EL, Chang S, et al. Endogenous oncogenic K-ras(G12D) stimulates proliferation and widespread neoplastic and developmental defects. Cancer Cell 2004;5:375-387.

16. Guerra C, Mijimolle N, Dhawahir A, Dubus P, Barradas M, Serrano M, et al. Tumor induction by an endogenous K-ras oncogene is highly dependent on cellular context. Cancer Cell 2003;4:111-120.

17. Schuhmacher A J, Guerra C, Sauzeau V, Cañamero M, Bustelo XR, Barbacid M. A mouse model for Costello syndrome reveals an Ang II-mediated hypertensive condition. J Clin Invest 2008; 118:2169-2179.

18. Chen X, Mitsutake N, LaPerle K, Akeno N, Zanzonico P, Longo VA, et al. Endogenous expression of HrasG12V induces developmental defects and neoplasms with copy number imbalances of the oncogene. Proc Natl Acad Sci USA 2009; 106:7979-7984. 
19. Hernández-Porras I, Fabbiano S, Schuhmacher AJ, Aicher A, Cañamero M, Cämara JA, et al. K-RasV14I recapitulates Noonan syndrome in mice. Proc Natl Acad Sci USA 2014;111:16395-16400.

20. Jonkers J, Meuwissen R, Van der Gulden H, Peterse H, van der Valk M, Berns A. Synergistic tumor suppressor activity of BRCA2 and p53 in a conditional mouse model for breast cancer. Nat Genet 2001;29:418-425.

21. Ruzankina Y, Pinzon-Guzman C, Asare A, Ong T, Pontano L, Cotsarelis G, et al. Deletion of the developmentally essential gene ATR in adult mice leads to agerelated phenotypes and stem cell loss. Cell Stem Cell 2007;1:113-126.

22. Guerra C, Schuhmacher AJ, Cañamero M, Grippo PJ, Verdaguer L, Pérez-Gallego L, et al. Chronic Pancreatitis is essential for induction of pancreatic ductal adenocarcinoma by K-Ras oncogenes in adult mice. Cancer Cell 2007;11:291-302.

23. Blasco RB, Francoz S, Santamaría D, Cañamero M, Dubus P, Charron J, et al. cRaf, but not B-Raf, is essential for development of K-Ras oncogene-driven nonsmall cell lung carcinoma. Cancer Cell 2011;19:652-663.

24. Itahana K, Campisi J, Dimri GP. Methods to detect biomarkers of cellular senescence: the senescence-associated $\beta$-Galactosidase assay. Methods $\mathrm{Mol}$ Biol 2007;371:21-31.

25. Drosten M, Sum EY, Lechuga CG, Simón-Carrasco L, Jacob HK, García-Medina R, et al. Loss of p53 induces cell proliferation via Ras-independent activation of the Raf/Mek/Erk signaling pathway. Proc Natl Acad Sci USA 2014;111:15155-15160.

26. Lakso M, Pichel JG, Gorman JR, Sauer B, Okamoto Y, Lee E, et al. Efficient in vivo manipulation of mouse genomic sequences at the zygote stage. Proc Natl Acad Sci USA 1996;93:5860-5865. 
27. Mainardi S, Mijimolle N, Francoz S, Vicente-Dueñas C, Sánchez-García I, Barbacid M. Identification of cancer initiating cells in K-ras driven lung adenocarcinoma. Proc Natl Acad Sci USA 2014;111:255-260.

28. Wendorff AA, Koch U, Wunderlich FT, Wirth S, Dubey C, Brüning JC, et al. Hes1 is a critical but context-dependent mediator of canonical Notch signaling in lymphocyte development and transformation. Immunity 2010;33:671-684.

29. Cox J, Hein MY, Luber CA, Paron I, Nagaraj N, Mann M. Accurate proteome-wide label-free quantification by delayed normalization and maximal peptide ratio extraction, termed MaxLFQ. Mol Cell Proteomics 2014;13:2513-2526.

30. Wright CJ, McCormack PL. Trametinib: first global approval. Drugs 2013;73:12451254.

31. Serrano M, Lin AW, McCurrach ME, Beach D, Lowe SW. Oncogenic ras provokes premature cell senescence associated with accumulation of p53 and p16INK4a. Cell 1997;88:593-602.

32. Frisch SM, Mymryk JS. Adenovirus-5 E1A: paradox or paradigm. Nat Rev Mol Cell Biol 2002;3:441-452.

33. Wang MT, Holderfield M, Galeas J, Delrosario R, To MD, Balmain A, et al. K-Ras promotes tumorigenicity through suppression of non-canonical Wnt signaling. Cell 2015; $163: 1237-1251$.

34. Braun BS, Tuveson DA, Kong N, Le DT, Kogan SC, Rozmus J, et al. Somatic activation of oncogenic Kras in hematopoietic cells initiates a rapidly fatal myeloproliferative disorder. Proc Natl Acad Sci USA 2004;101:597-602.

35. Chan IT, Kutok JL, Williams IR, Cohen S, Kelly L, Shigematsu H, et al. Conditional expression of oncogenic K-ras from its endogenous promoter induces a myeloproliferative disease. J Clin Invest 2004; 113:528-538. 
36. Kindler T, Cornejo MG, Scholl C, Liu J, Leeman DS, Haydu JE, et al. K-RasG12Dinduced T-cell lymphoblastic lymphoma/leukemias harbor Notch1 mutations and are sensitive to $\gamma$-secretase inhibitors. Blood 2008;112:3373-3382.

37. Lampson BJ, Pershing NL, Prinz JA, Lacsina JR, Marzluff WF, Nicchitta CV, et al. Rare codons regulate KRas oncogenesis. Curr Biol 2013;23:70-75.

38. Pershing NL, Lampson BL, Belsky JA, Kaltenbrun E, MacAlpine DM, Counter CM. Rare codons capacitate Kras-driven de novo tumorigenesis. J Clin Invest 2015; 125:222-233.

39. To MD, Wong CE, Karnezis AN, Del Rosario R, Di Lauro R, Balmain A. Kras regulatory elements and exon $4 \mathrm{~A}$ determine mutation specificity in lung cancer. Nat Genet 2008; $40: 1240-1244$.

40. Gao S, Ho D, Vatner DE, Vatner SF. Echocardiography in mice. Curr Protoc Mouse Biol 2011;1:71-83.

41. Navas C, Hernández-Porras I, Schuhmacher AJ, Sibilia M, Guerra C, Barbacid M. EGR receptor signaling is essential for K-Ras oncogene-driven pancreatic ductal adenocarcinoma. Cancer Cell 2012;22:318-330.

42. Shevchenko A, Tomas H, Havlis J, Olsen JV, Mann M. In-gel digestion for mass spectrometric characterization of proteins and proteomes. Nat. Protoc. 2006;1:28562860. 


\section{FIGURE LEGENDS}

Figure 1. H-Ras and K-Ras proteins are functionally bioequivalent.

A, Heart function as determined by percentage of ejection fraction in the left ventricle of KrasKI ( $n=9$, solid bar), HrasKI ( $n=10$, open bar) or HrasKI;H-Ras ${ }^{-/}(n=9$, grey bar) mice. Data are represented as mean $\pm \mathrm{SD}$.

B, Mean arterial pressure of KrasKI ( $n=6$, solid bar), HrasKI $(n=7$, open bar) or HrasKI;H-Ras ${ }^{--}(n=7$, grey bar $)$ mice. Data are represented as mean \pm SD. ${ }^{* * *} P<$ 0.001 (unpaired Student $t$ test).

C, Cardiomyocyte area in the left ventricle of KrasKI ( $n=4$, solid bar), HrasKI $(n=4$, open bar) or HrasKI;H-Ras ${ }^{-/-}(n=5$, grey bar) mice. Data are represented as mean \pm SD. ${ }^{* * *} P<0.001$ (unpaired Student $t$ test).

D, Masson's trichrome staining for fibrosis in sections obtained from the left ventricle of representative HrasKI and HrasKI;H-Ras ${ }^{-/-}$mice. (Scale bars, $200 \mu \mathrm{m}$.)

Figure 2. Phenotypic consequences of the expression of H-Ras ${ }^{\mathrm{G} 12 \mathrm{~V}}$ and K-Ras ${ }^{\mathrm{G} 12 \mathrm{~V}}$ oncoproteins from the K-Ras locus in adult mice.

A, Schematic representation of K-Ras wild-type $\left(\mathrm{K}^{+}\right), \mathrm{K}-\operatorname{Ras}^{\mathrm{LSLG12Vgeo}}\left(\mathrm{K}^{\mathrm{V} 12}\right)$ and $\mathrm{K}-$ $\operatorname{Ras}^{\mathrm{LSLH}-\mathrm{RasG12V}}\left(K^{\mathrm{HRasV12}}\right)$ alleles. The H-Ras ${ }^{\mathrm{G} 12 \mathrm{~V}}$ cDNA (blue) was knocked-in into exon 1 of the endogenous K-Ras locus (red) along with transcriptional termination sequences (STOP) and a Hygromycin-expressing selection cassette (Hyg) flanked by loxP sequences (closed triangles) upstream of exon 1, at the same location as in the $K^{\mathrm{V} 12}$ allele. The exon 1 encoding the oncogenic G12V mutation is indicated by an asterisk. The three alleles share the same ATG initiator codon sequences. 
B, Schematic representation of the coding exons (1-4) present in the endogenous H-Ras locus and the H-Ras cDNA (cDNA). The non-coding domains of exons 1 and 4 are indicated by open boxes.

C, Western blot analysis of H-Ras expression in $\mathrm{H}-\mathrm{Ras}^{-/-}$MEFs infected with empty lentiviruses (Vector), lentiviruses expressing the $1.6 \mathrm{kbp}$ DNA fragment encompassing the H-Ras genomic sequences shown in B (Genomic) and or the H-Ras cDNA (cDNA). GAPDH expression served as a loading control.

D, Survival of $K^{+}$; hUBC-CreERT2 ${ }^{+/ \mathrm{T}}$ (green dots, $n=6$ ), $K^{\mathrm{V} 12}$;hUBC-CreERT2 ${ }^{+/ \mathrm{T}}$ (red dots, $n=19$ ) or $K^{\mathrm{HRasV12}}$; hUBC-CreERT2 ${ }^{+/ \mathrm{T}}$ (blue dots, $n=16$ ) mice subjected to a continuous Tmx diet at 4 weeks of age (solid arrow).

E, H\&E staining of lung and stomach sections obtained from $K^{+}$; hUBC-CreERT2 ${ }^{+/ T}$,

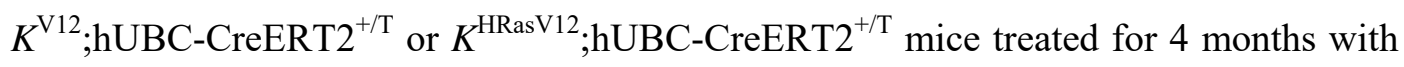
Tmx diet. Asterisks indicate adenomas (lung) or papillomas (stomach) in $K^{\mathrm{V} 12}$;hUBC$\mathrm{CreERT}^{+/ \mathrm{T}}$ animals $\left(K^{\mathrm{V} 12}\right)$. Arrowheads show the normal stratified epithelium of the forestomach in $K^{+}$; hUBC-CreERT2 ${ }^{+/ \mathrm{T}}\left(K^{+}\right)$, and $K^{\mathrm{HRasV12}} ; \mathrm{hUBC-CreERT2}{ }^{+/ \mathrm{T}}\left(K^{\mathrm{HRasV} 12}\right)$ mice. (Scale bars, $200 \mu \mathrm{m}$.)

Figure 3. H-Ras ${ }^{\mathrm{G} 12 \mathrm{~V}}$, but not $\mathrm{K}-\mathrm{Ras}^{\mathrm{G} 12 \mathrm{~V}}$, induces hematopoietic tumors in adult mice.

A, Representative images of spleens obtained from $K^{+} ; \mathrm{hUBC}-\mathrm{CreERT2} 2^{+/ \mathrm{T}}, K^{\mathrm{V} 12} ; \mathrm{hUBC}$ $\mathrm{CreERT}^{+/ \mathrm{T}}$ or $\mathrm{K}^{\mathrm{HRasV} 12}$; hUBC-CreERT2 ${ }^{+/ \mathrm{T}}$ mice treated for 4 months with Tmx diet.

B, H\&E staining of spleen sections obtained from $K^{+}$; hUBC-CreERT2 ${ }^{+/ \mathrm{T}}, K^{\mathrm{V} 12}$;hUBC$\mathrm{CreERT}^{+/ \mathrm{T}}$ or $K^{\mathrm{HRasV} 12}$;hUBC-CreERT2 ${ }^{+/ \mathrm{T}}$ mice treated for 4 months with Tmx diet. White and red pulp are indicated by arrows and arrowheads, respectively. (Scale bars, $200 \mu \mathrm{m}$. 
C, Flow cytometry analysis of $\mathrm{Gr}^{+}$and $\mathrm{CD} 1 \mathrm{~b}^{+}$cells in spleens obtained from

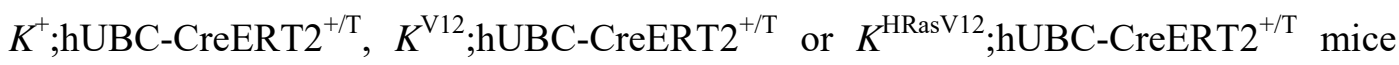
treated for 4 months with Tmx diet.

D, H\&E (above and middle) and CD3 IHC (bottom) staining in thymus sections obtained from $K^{+}$;hUBC-CreERT2 ${ }^{+/ \mathrm{T}}$ or $K^{\mathrm{HRasV} 12}$;hUBC-CreERT2 $2^{+/ \mathrm{T}}$ mice treated for 4 months with Tmx diet. (Scale bars, $5 \mathrm{~mm}$ [above], $25 \mu \mathrm{m}$ [middle, below].)

E, Flow cytometry analysis of $\mathrm{CD}^{+}$and $\mathrm{CD} 8^{+}$cells in thymuses obtained from $K^{+}$;hUBC-CreERT2 ${ }^{+/ \mathrm{T}}$ or $K^{\mathrm{HRasV12}}$;hUBC-CreERT2 ${ }^{+/ \mathrm{T}}$ mice treated for 4 months with Tmx diet.

Figure 4. K-Ras ${ }^{\mathrm{G} 12 \mathrm{~V}}$ and $\mathrm{H}-\mathrm{Ras}{ }^{\mathrm{G} 12 \mathrm{~V}}$ oncoproteins expressed from the K-Ras locus induce pancreatic lesions.

A, Number of low (P1) and high (P2/3) grade PanINs as well as PDACs (PDA) per mouse in one year-old $K^{\mathrm{V} 12} ;$ Elas-tTA/tetO-Cre (red circles, $n=13$ ) or $K^{\mathrm{HRasV} 12}$;ElastTA/tetO-Cre (blue circles, $n=10$ ) mice. Data are represented as mean (horizontal bars) $\pm \mathrm{SD}$.

B, Survival of $K^{\mathrm{V} 12} ; p 53^{\text {lox/lox}} ;$ Elas-tTA/tetO-Cre $\left(K^{\mathrm{V} 12} ; p 53^{\text {lox/lox }}\right.$, red dots, $\left.n=22\right)$ or $K^{\mathrm{HRasV12}} ; p 53^{\text {lox/lox}} ;$ Elas-tTA/tetO-Cre mice $\left(K^{\mathrm{HRasV} 12} ; p 53^{\text {lox/lox }}\right.$, blue dots, $\left.n=19\right)$.

C, Number of low (P1) and high (P2/3) grade PanINs as well as PDACs (PDA) per mouse in 10 week-old $K^{\mathrm{V} 12} ; p 53^{\text {lox/lox}} ;$ Elas-tTA/tetO-Cre (red circles, $n=9$ ) or $K^{\mathrm{HRasV12}} ; p 53^{\text {lox/lox}} ;$ Elas-tTA/tetO-Cre (blue circles, $\left.n=8\right)$ mice. Data are represented as mean (horizontal bars) $\pm \mathrm{SD}$.

D, Acinar cell explants isolated from pancreata of 6 to 8 week old $K^{\mathrm{V} 12}$;Elas-tTA/tetOCre $\left(K^{\mathrm{V} 12}\right.$, red bars, $\left.n=6\right)$ and $K^{\mathrm{HRasV12}} ;$ Elas-tTA/tetO-Cre $\left(K^{\mathrm{HRasV} 12}\right.$, blue bars, $\left.n=7\right)$ mice were incubated in absence or presence of the indicated growth factors. The 
number of metaplasias was determined after five days in culture. Data are represented as mean $\pm \mathrm{SD} . * * * P<0.001$ (unpaired Student $t$ test).

Figure 5. H-Ras ${ }^{\mathrm{G} 12 \mathrm{~V}}$ expressed from the K-Ras locus induces robust downstream signaling in lung tissue.

A, Top: IHC staining for $\mathrm{pErk}^{+}$cells in lung sections obtained from $K^{\mathrm{V} 12}$,hUBC$\mathrm{CreERT}^{+/ \mathrm{T}}$ or $\mathrm{K}^{\mathrm{HRasV12}}$;hUBC-CreERT2 ${ }^{+/ \mathrm{T}}$ mice subjected to Tmx diet for the indicated time. (Scale bars, $250 \mu \mathrm{m}$.) Bottom: Quantification of the percentage of pERK ${ }^{+}$cells in the lung sections shown above obtained from $K^{\mathrm{V} 12} ; \mathrm{hUBC}-\mathrm{CreERT} 2^{+/ \mathrm{T}}\left(K^{\mathrm{V} 12}\right.$, red bars, $n$ $=3)$ or $K^{\mathrm{HRasV12}}$;hUBC-CreERT2 $2^{+/ \mathrm{T}}\left(K^{\mathrm{HRasV12}}\right.$, blue bars, $\left.n=3\right)$ mice. Data are represented as mean $\pm \mathrm{SD} .{ }^{* * *} P<0.001$ (unpaired Student $t$ test).

B, Western blot analysis of H-Ras, pErk1/2, Erk1/2, pAkt, Akt, p16Ink4a and p19Arf expression in total lung extracts obtained from $K^{\mathrm{V} 12}$; hUBC-CreERT2 ${ }^{+/ \mathrm{T}}$ or $K^{\mathrm{HRasV12}} ; \mathrm{hUBC}^{\mathrm{C} C r e E R T 2}{ }^{+/ \mathrm{T}}$ mice exposed to Tmx diet for the indicated time. GAPDH expression served as a loading control.

C, Relative quantification of the levels of expression of K-Ras ${ }^{\mathrm{G} 12 \mathrm{~V}}$ and H-Ras ${ }^{\mathrm{G} 12 \mathrm{~V}}$ oncoproteins by label-free quantification (LFQ) in lungs obtained from $K^{+}$;hUBC$\mathrm{CreERT2}^{+/ \mathrm{T}}(n=6), K^{\mathrm{V} 12}$;hUBC-CreERT2 ${ }^{+/ \mathrm{T}}(n=6)$ or $K^{\mathrm{HRasV} 12} ; \mathrm{hUBC}-C r e E R T 2^{+/ \mathrm{T}}(n$ =6) mice treated for 2 months with Tmx diet. The tryptic peptide LVVVGAVGVGK was used to detect expression of both $\mathrm{K}-\mathrm{Ras}^{\mathrm{G} 12 \mathrm{~V}}$ and H-Ras ${ }^{\mathrm{G} 12 \mathrm{~V}}$ proteins. Data are represented as mean $\pm \mathrm{SD}$.

D, Total Ras-GTP levels in lungs obtained from $K^{\mathrm{V} 12}$;hUBC-CreERT2 ${ }^{+/ \mathrm{T}}$ or $K^{\mathrm{HRasV12}} ; \mathrm{hUBC-CreERT2} 2^{+/ \mathrm{T}}$ mice treated with Tmx diet for the indicated time. GAPDH was used as a loading control. 
Figure 6. H-Ras ${ }^{\mathrm{G} 12 \mathrm{~V}}$ expressed from the K-Ras locus induces a senescence-like arrest in lung tissue that results in subsequent elimination of cells.

A, Southern blot analysis of DNA isolated from lung tissue obtained from 4 week old $K^{\mathrm{HRasV12}} ; \mathrm{hUBC}-\mathrm{CreERT} 2^{+/ \mathrm{T}}$ mice exposed to a Tmx diet for 4 weeks either immediately ending the treatment (left) or after mice were maintained for 8 additional weeks in a regular diet (center and right). The latter mice were either left untreated during the additional 8 week period (center) or treated daily with $1 \mathrm{mg} / \mathrm{kg}$ of Trametinib, a selective MEK inhibitor (right). DNA isolated from thymus tissue was used as control. The migration (open arrowheads) and sizes (solid arrowheads) of the diagnostic SphI+KpnI DNA fragments for the recombined K-Ras ${ }^{\mathrm{H}-\mathrm{RasG} 12 \mathrm{~V}}$ allele that expresses the H-Ras ${ }^{\mathrm{G} 12 \mathrm{~V}}$ oncoprotein and the non-recombined K-Ras ${ }^{\text {LSLH-RasG12V }}$ allele that does not allow H-Ras ${ }^{\mathrm{G} 12 \mathrm{~V}}$ expression are indicated. Note the disappearance of the recombined K$\operatorname{Ras}^{\mathrm{H}-\mathrm{RasG12V}}$ allele in lung but not thymus tissue. Lung tissue from mice treated with Trametinib also retains the recombined K-Ras ${ }^{\mathrm{H}-\mathrm{RasG} 12 \mathrm{~V}}$ allele.

B, Relative expression levels of p16Ink4a and p19Arf mRNAs in total lung extracts from $K^{\mathrm{V} 12} ;$ hUBC-CreERT2 ${ }^{+/ \mathrm{T}}\left(K^{\mathrm{V} 12}\right.$, red bars, $\left.n=3\right)$ or $K^{\mathrm{HRavV} 12} ; \mathrm{hUBC}^{\mathrm{C} C r e E R T 2}{ }^{+/ \mathrm{T}}$ $\left(K^{\mathrm{HRasV12}}\right.$, blue bars, $\left.n=3\right)$ mice exposed to $\mathrm{Tmx}$ diet for the indicated time, as determined by qRT-PCR analysis. GAPDH expression levels were used for normalization. Data are represented as mean $\pm \mathrm{SD}$. ${ }^{* * *} P<0.001$ (unpaired Student $t$ test).

Figure 7. H-Ras ${ }^{\mathrm{G} 12 \mathrm{~V}}$, but not $\mathrm{K}-\mathrm{Ras}^{\mathrm{G} 12 \mathrm{~V}}$ expressed from the K-Ras locus induces senescence in MEFs. 
A, Western blot analysis of the indicated proteins expressed in $K^{\mathrm{V} 12}$ or $K^{\mathrm{HRasV} 12}$ MEFs infected with Adeno-Cre particles for the indicated time. GAPDH expression served as a loading control.

B, Growth curve of $K^{\mathrm{V} 12}$ or $K^{\mathrm{HRasV12}}$ MEFs infected with Adeno-GFP (open circles) or Adeno-Cre particles (closed circles) for the indicated time after stable infection with empty retroviruses (Vector) or retroviruses expressing the Ad5 E1A oncoprotein (E1A). Data are represented as mean $\pm \mathrm{SD}$.

C, Percentage of senescence-associated $\beta$-Galactosidase (SA- $\beta$ Gal) positive cells in $K^{\mathrm{V} 12}$ or $K^{\mathrm{HRasV12}}$ MEFs stably infected with empty retroviruses $(\mathrm{V})$ or retroviruses expressing the Ad5 E1A oncoprotein (E1A) 4 days after infection with Adeno-Cre particles. Data are represented as mean \pm SD. ${ }^{* * *} P<0.001$ (unpaired Student $t$ test).

D, Focus formation in $K^{\mathrm{V} 12}$ or $K^{\mathrm{HRas} 12}$ MEFs stably infected with empty retroviruses (V) or retroviruses expressing Ad5 E1A (E1A) 14 days after infection with Adeno-Cre particles. Data are represented as mean \pm SD. ${ }^{* * *} P<0.001$ (unpaired Student $t$ test).

E, Relative quantification of the levels of expression of the K-Ras ${ }^{\mathrm{G} 12 \mathrm{~V}}$ and H-Ras ${ }^{\mathrm{G} 12 \mathrm{~V}}$ oncoproteins by label-free quantification (LFQ) in $K^{\mathrm{V} 12}$; hUBC-CreERT2 ${ }^{+/ \mathrm{T}}$ (red bars, $n$ $=3$ ) or $K^{\mathrm{HRasV12}}$;hUBC-CreERT2 ${ }^{+/ \mathrm{T}}$ MEFs (blue bars, $n=3$ ) 4 days after infection with Adeno-Cre particles. The tryptic peptide LVVVGAVGVGK was used to detect expression of K-Ras ${ }^{\mathrm{G} 12 \mathrm{~V}}$ and $\mathrm{H}-\mathrm{Ras}^{\mathrm{G} 12 \mathrm{~V}}$ proteins. Data are represented as mean $\pm \mathrm{SD}$.

F, Western blot analysis of H-Ras protein expression (H-Ras and H-Ras ${ }^{\mathrm{G} 12 \mathrm{~V}}$ ) driven by the K-Ras locus in $K^{\mathrm{HRasV12}}$ MEFs upon infection with Adeno-Cre particles for the indicated time and by the H-Ras locus in H-Ras ${ }^{\mathrm{G} 12 \mathrm{~V}}$ MEFs. Expression of Ras effector proteins pErk1/2, Erk1/2, pAkt and Akt was also analyzed. GAPDH expression served as loading control. 
Fig. 1

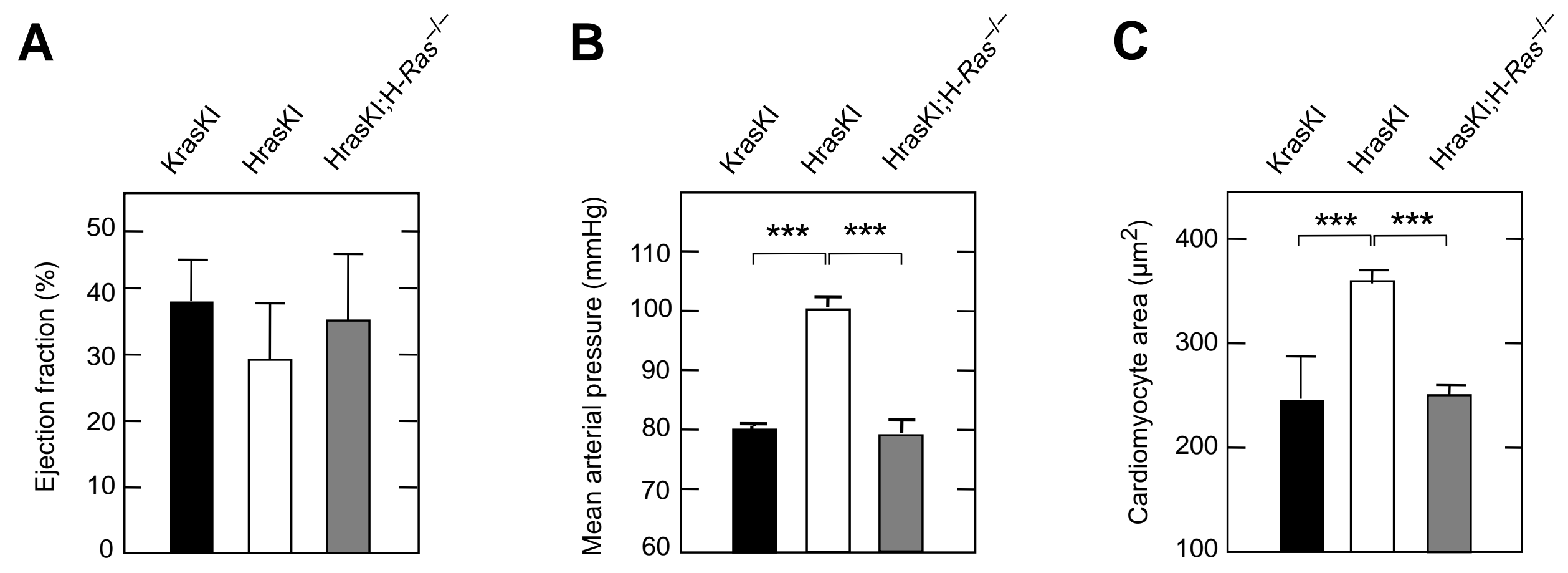

D

HrasKI HrasKl;H-Ras ${ }^{-1-}$

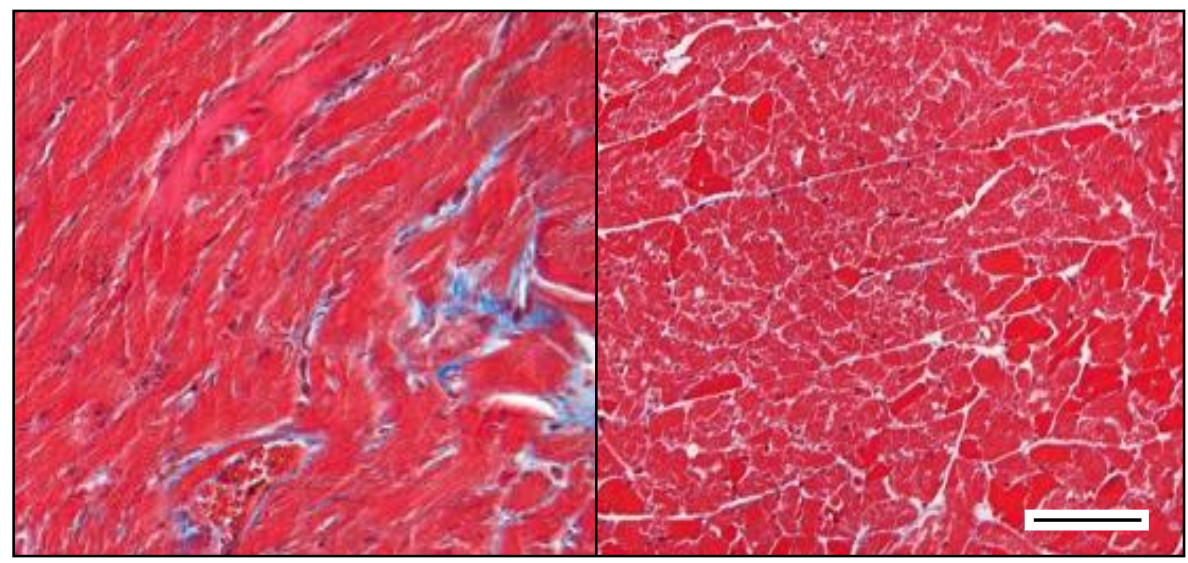


A

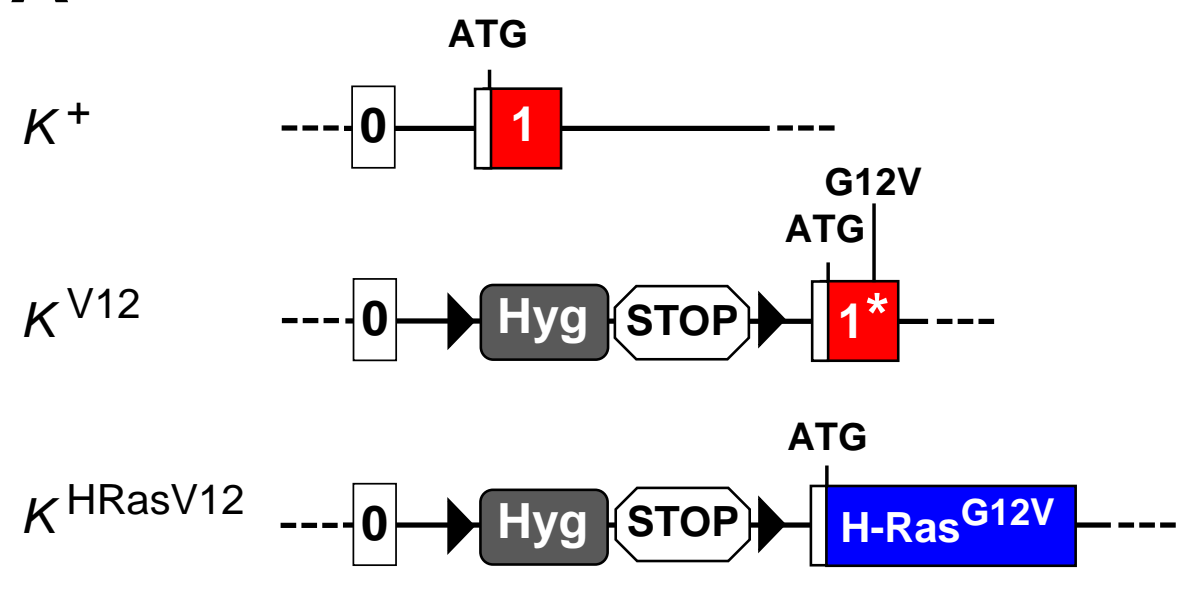

D

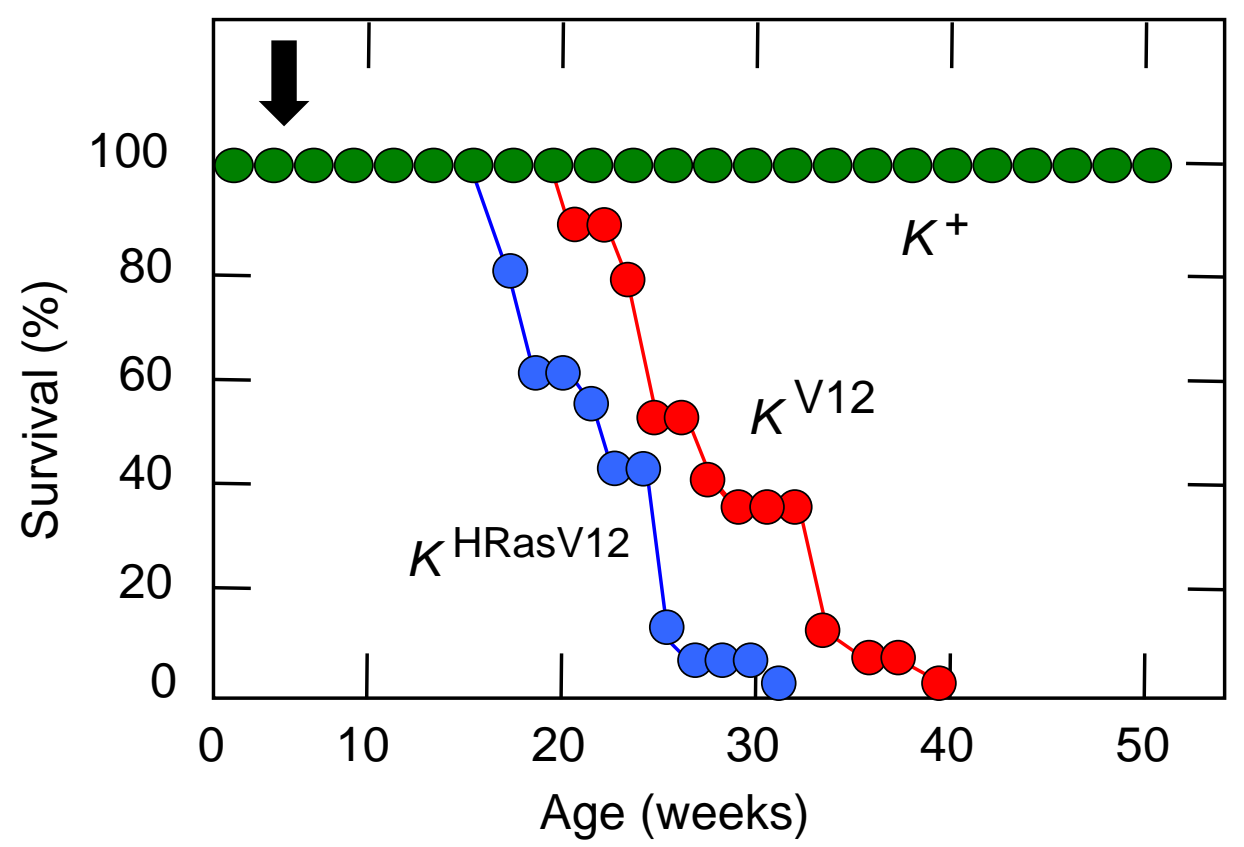

B

$\mathrm{H}$-Ras genomic DNA

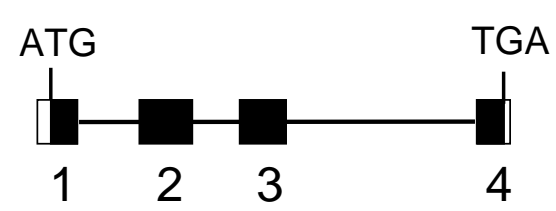

$\mathrm{H}$-Ras CDNA

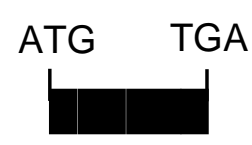

C

Fig. 2 
A

Author manuscripts have been peer reviewed and accepted for publication but have not yet been editedFig. 3
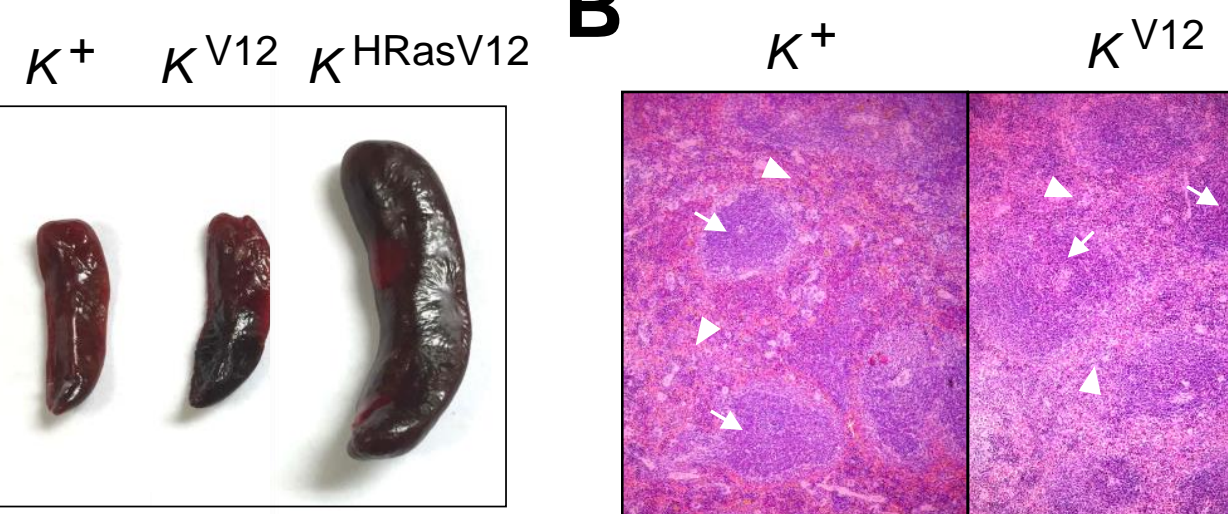

$K^{\text {HRasV12 }}$

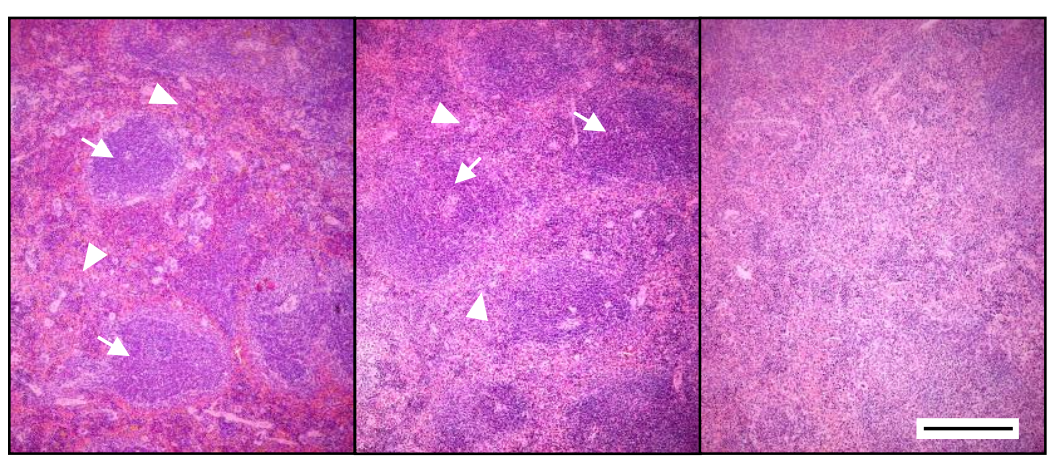

C

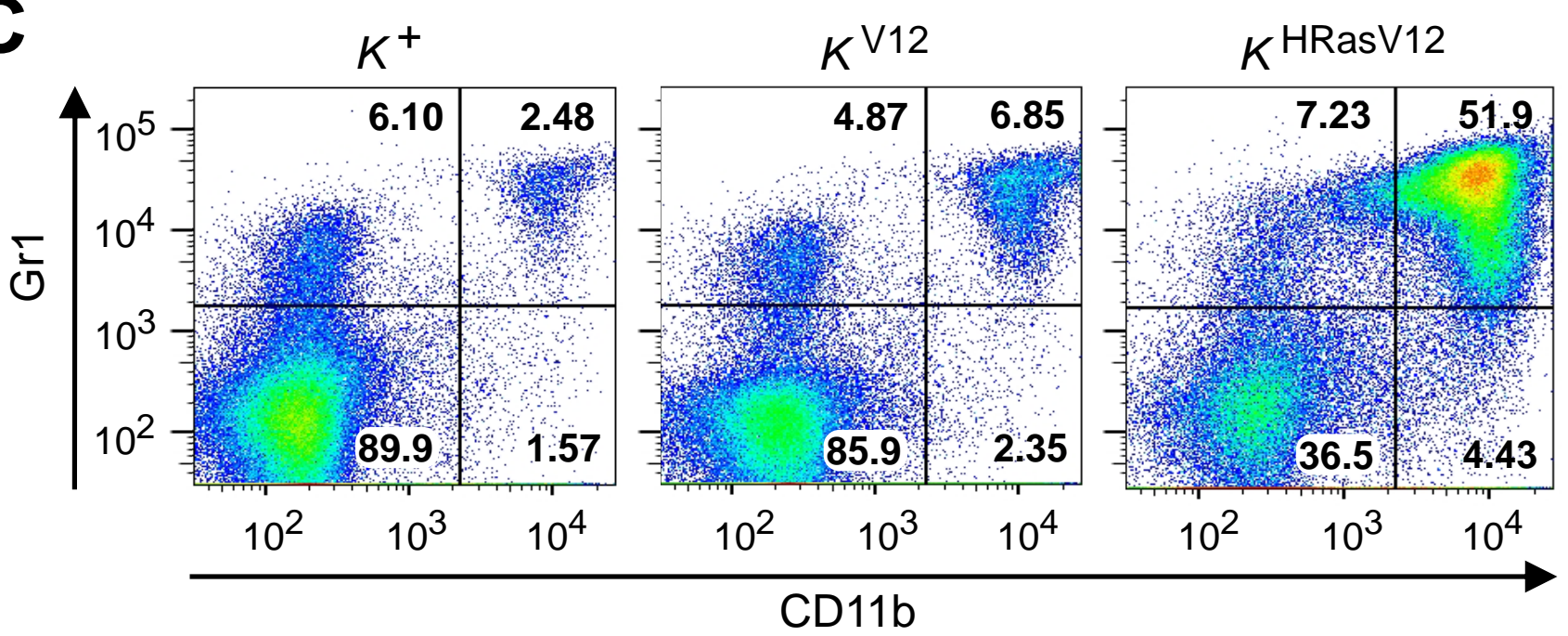

D
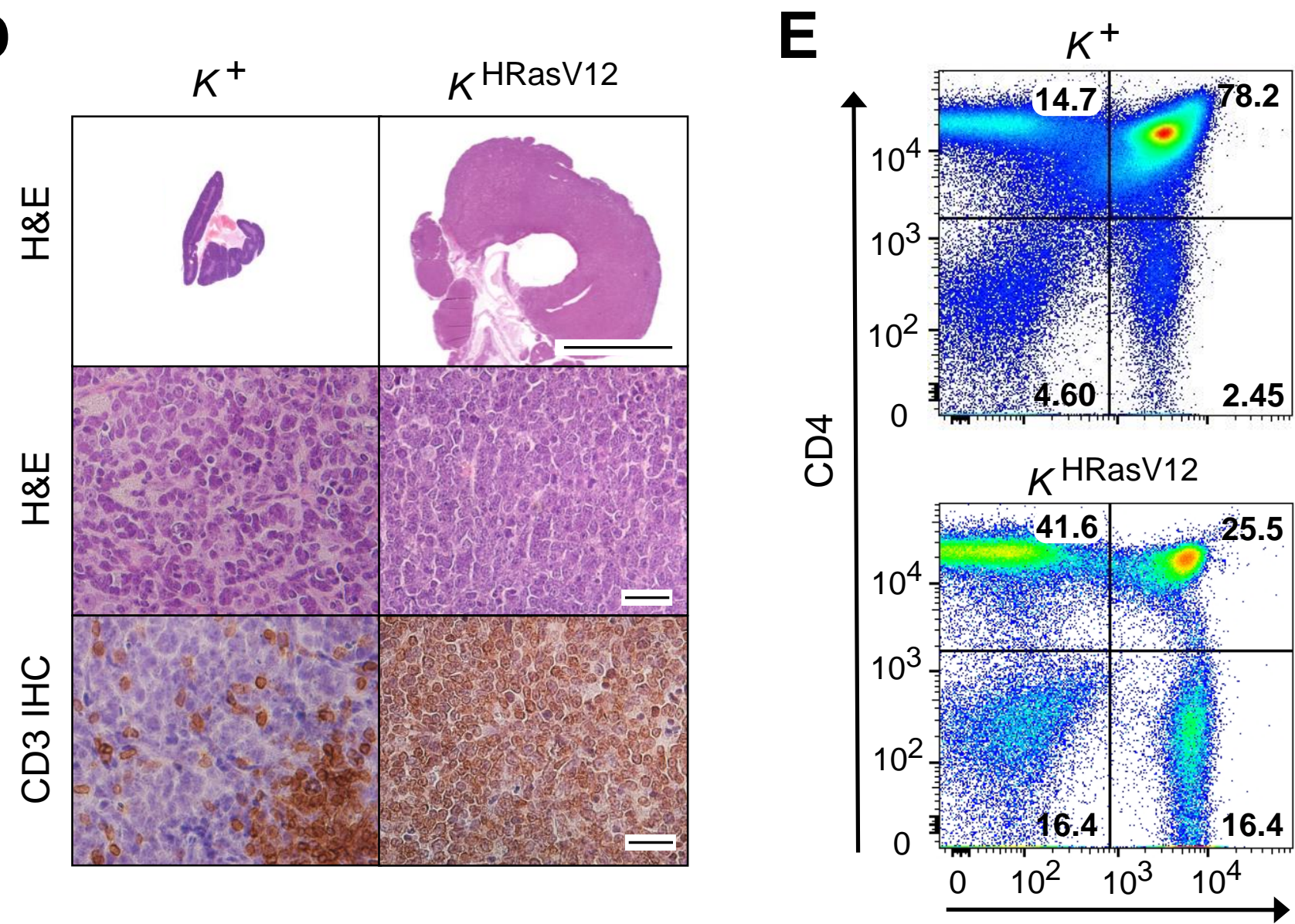

Downloaded from cancerres.aacrjournals.org on August 27, 2018. @ 2016 American As\$\&\&ation for Cancer Research. 
A

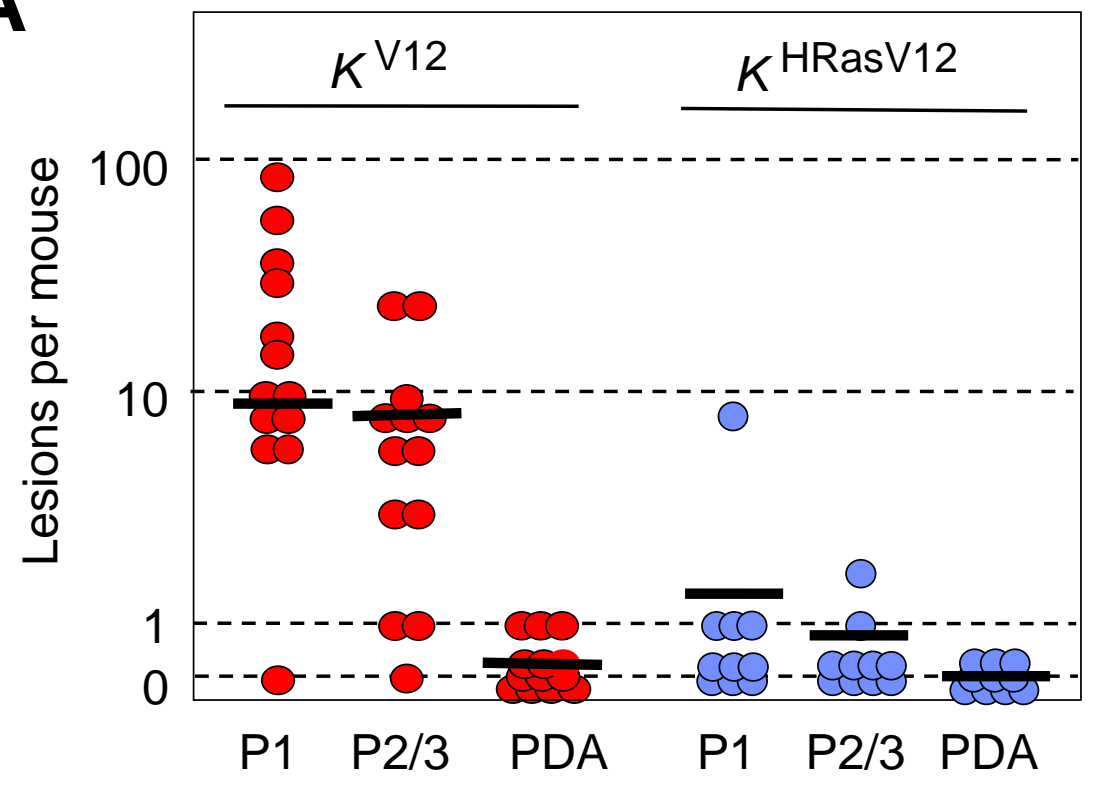

C

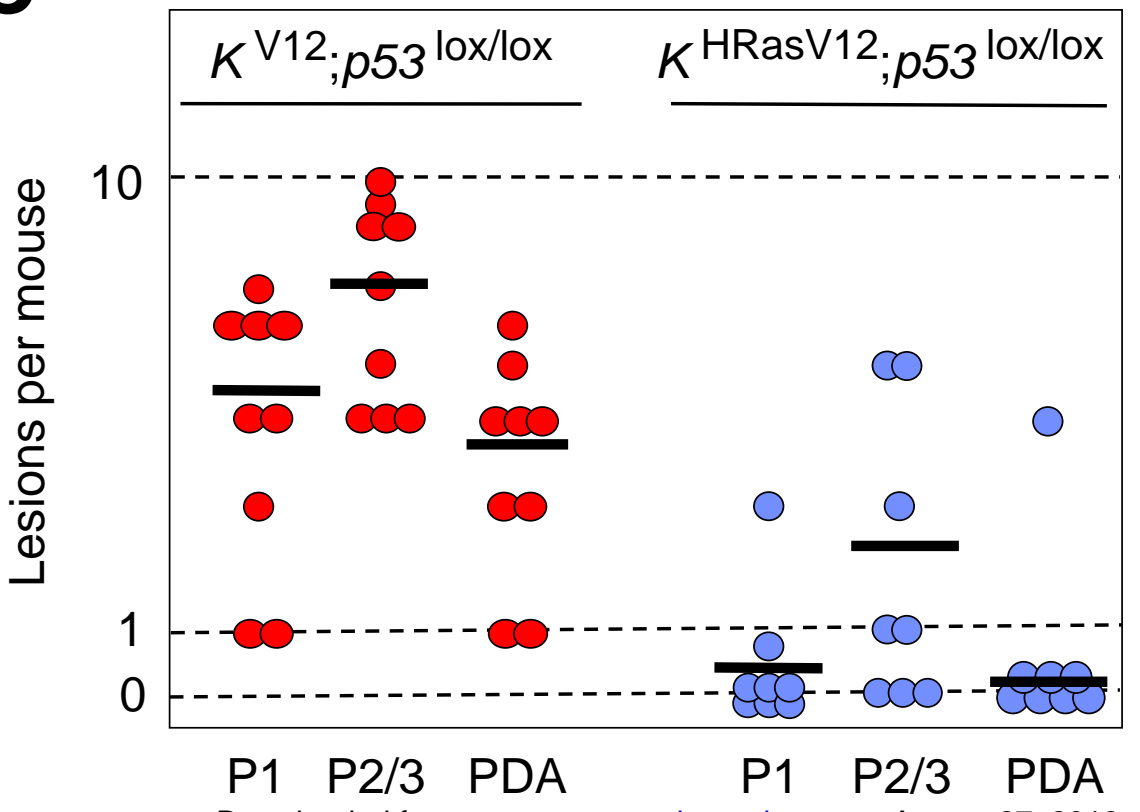

Downloaded from cancerres.aacrjournals.org on August 27, 2018. ๑ 2016 American Association for Cancer

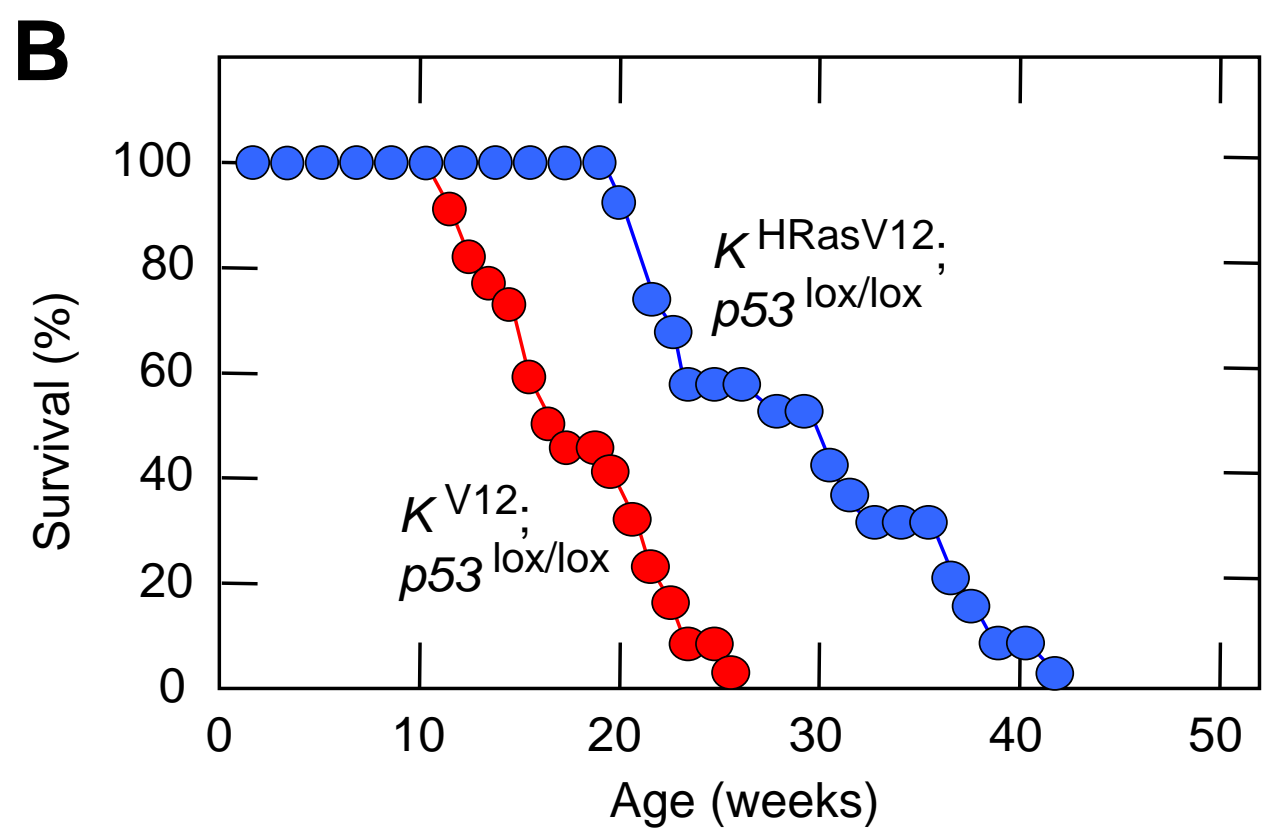

D

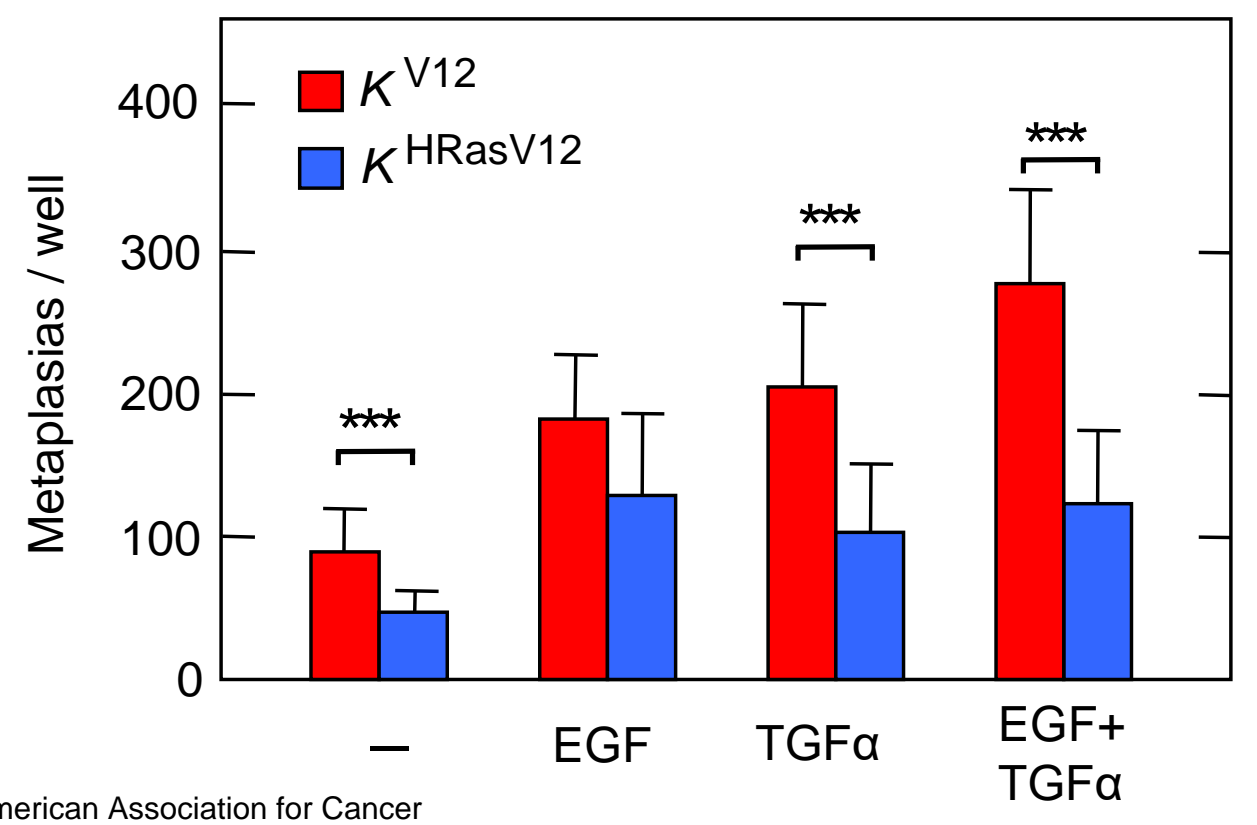


A
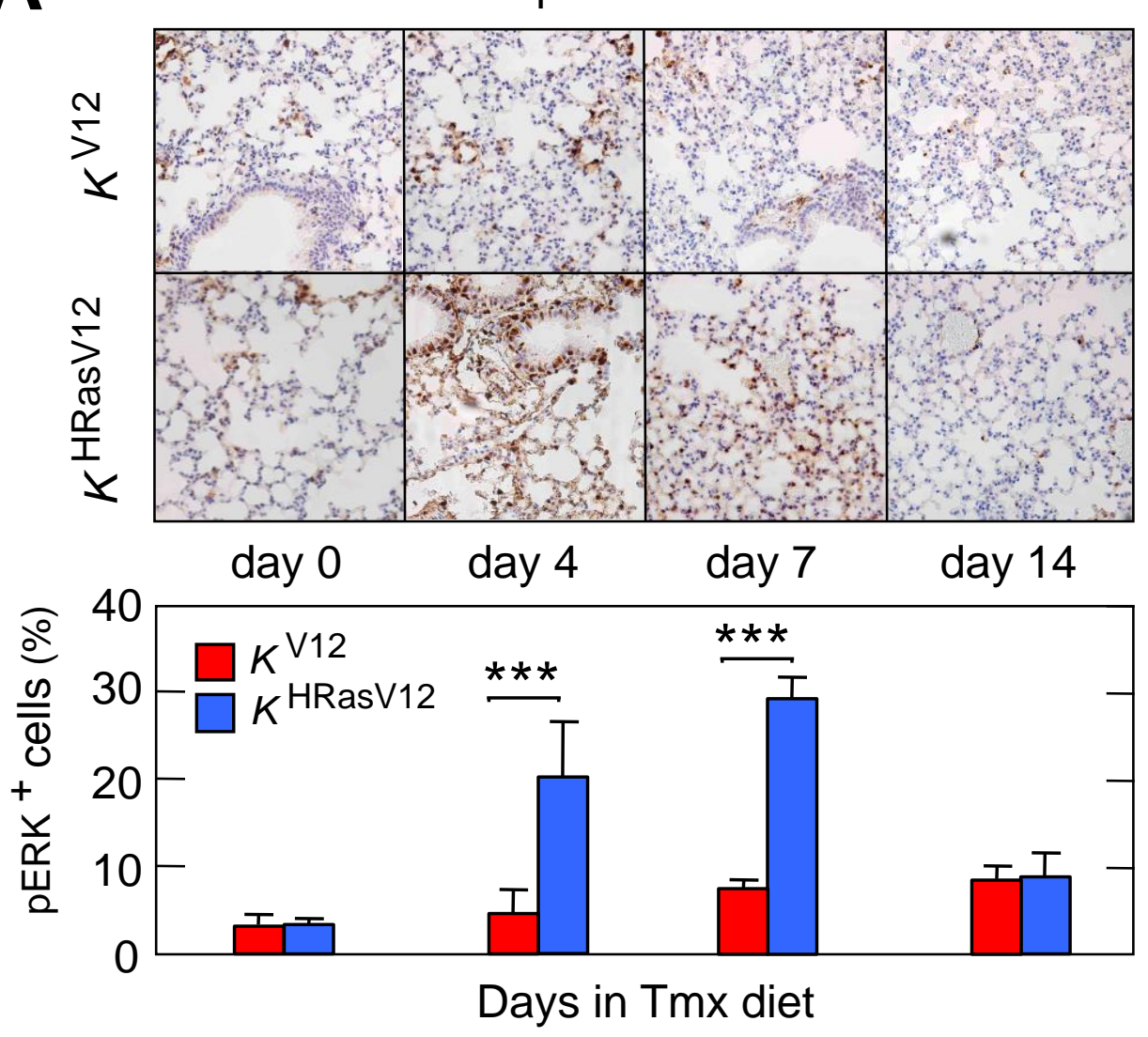

C

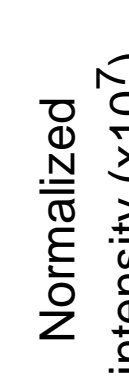

$K^{+} \quad K^{\mathrm{V} 12} \quad K^{\text {HRasV12 }}$

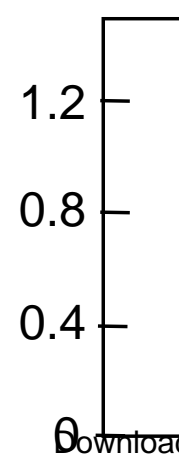

\section{$K+K V 12-K$ HRasv12}

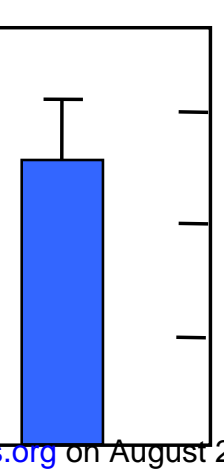

$K^{\mathrm{V} 12}$

Fig. 5

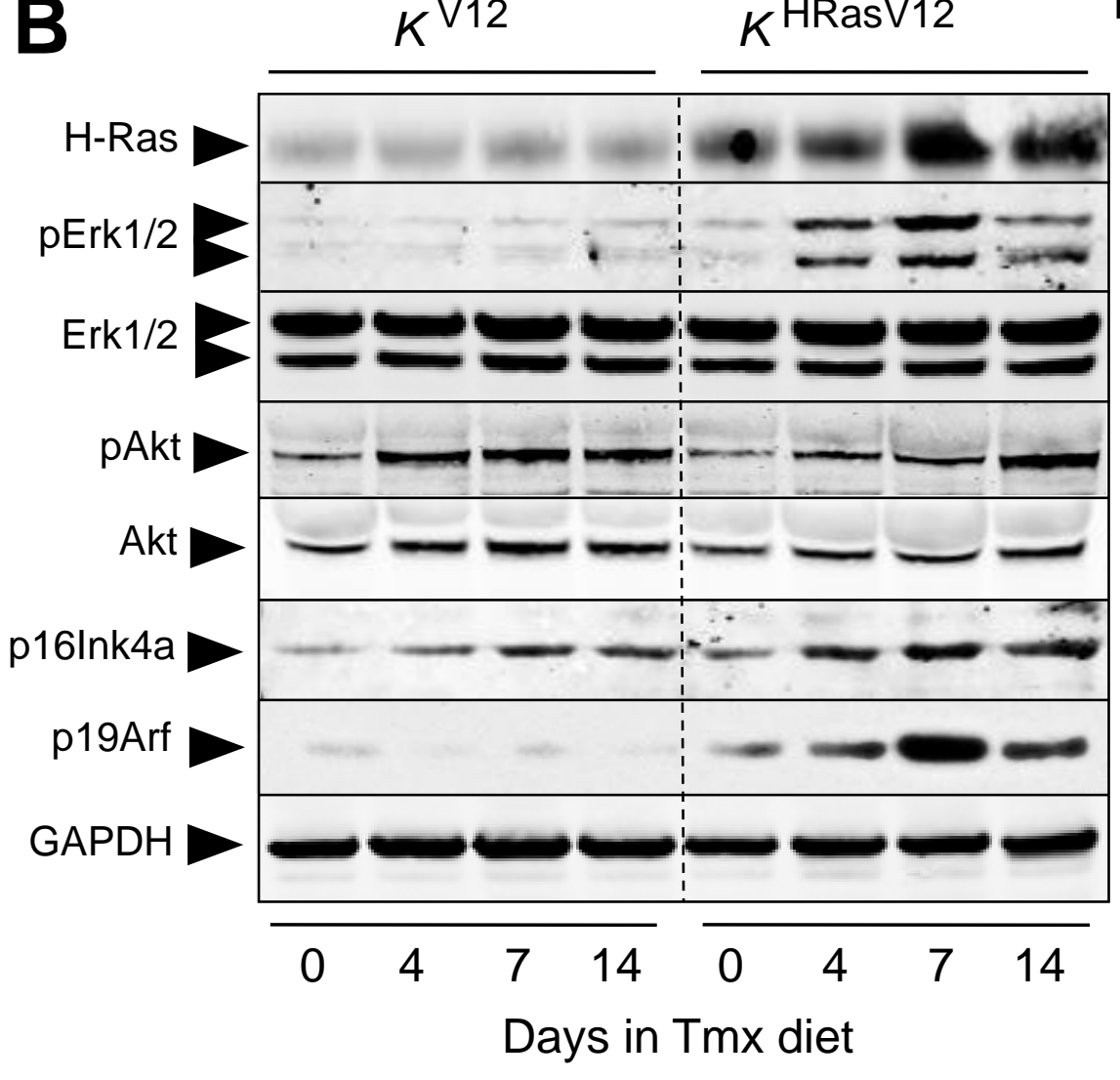

D

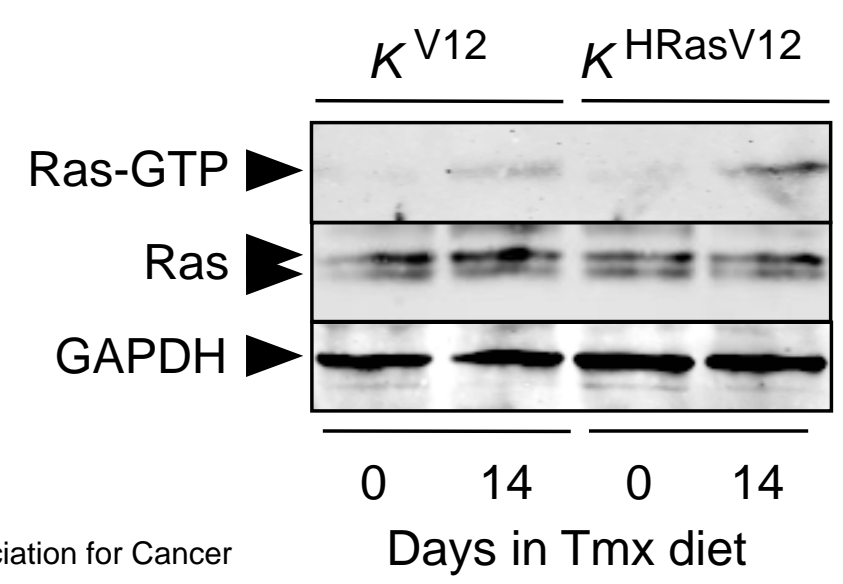




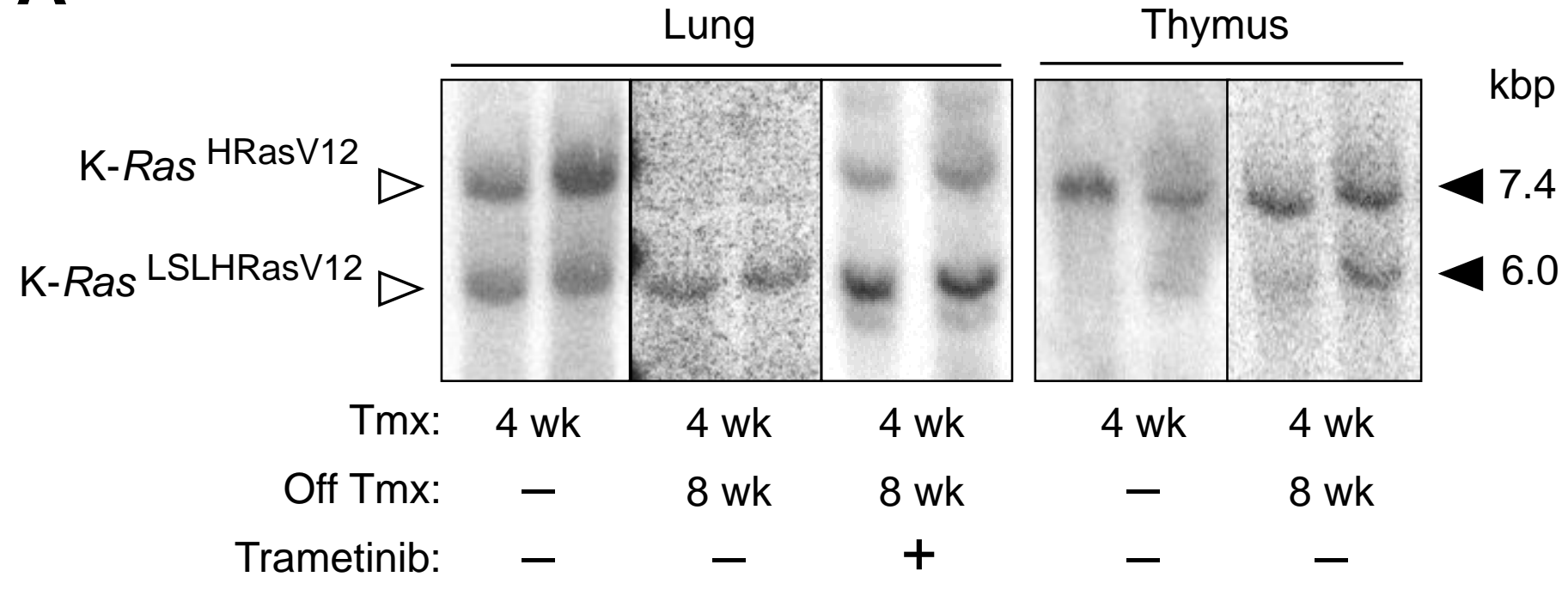

B

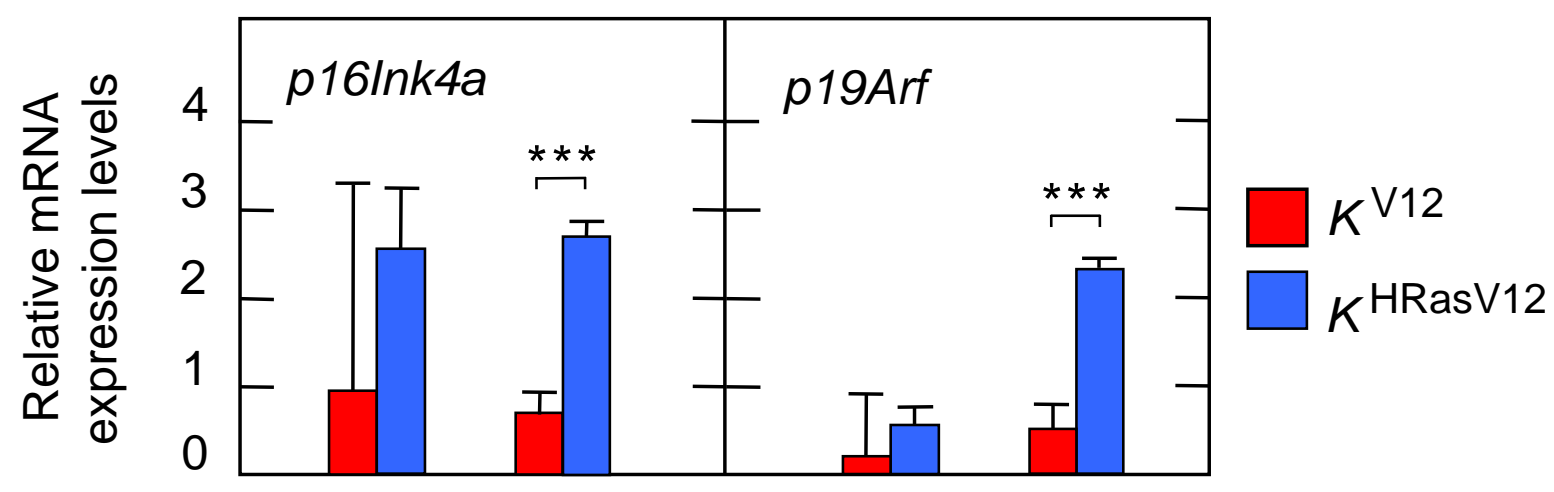




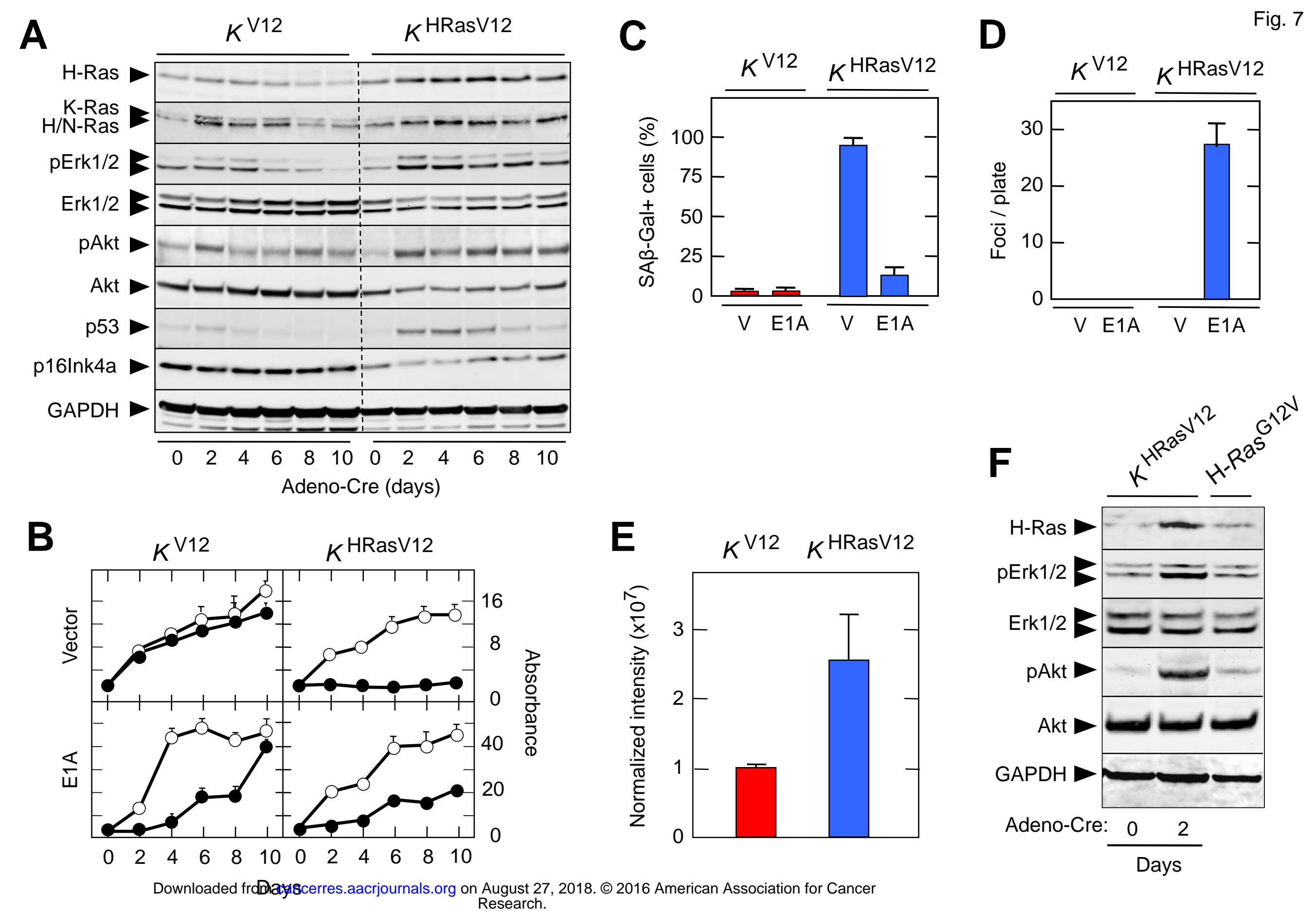




\section{$\mathrm{H}-$ Ras and K-Ras oncoproteins induce different tumor spectra when driven by the same regulatory sequences}

Matthias Drosten, Lucía Simón-Carrasco, Isabel Hernández-Porras, et al.

Cancer Res Published OnlineFirst November 21, 2016.

Updated version Access the most recent version of this article at: doi:10.1158/0008-5472.CAN-16-2925

Supplementary Access the most recent supplemental material at:

Material http://cancerres.aacrjournals.org/content/suppl/2016/11/19/0008-5472.CAN-16-2925.DC1

Author Author manuscripts have been peer reviewed and accepted for publication but have not yet been Manuscript edited.

\section{E-mail alerts Sign up to receive free email-alerts related to this article or journal.}

Reprints and To order reprints of this article or to subscribe to the journal, contact the AACR Publications Subscriptions Department at pubs@aacr.org.

Permissions To request permission to re-use all or part of this article, use this link http://cancerres.aacrjournals.org/content/early/2016/11/19/0008-5472.CAN-16-2925.

Click on "Request Permissions" which will take you to the Copyright Clearance Center's (CCC) Rightslink site. 